\title{
FINANCE AND SOCIETY: ON THE FOUNDATIONS OF CORPORATE SOCIAL RESPONSIBILITY
}

\author{
Hao Liang, Luc Renneboog ${ }^{1}$
}

\begin{abstract}
We investigate the roles of legal origins and political institutions-believed to be the fundamental determinants of economic outcomes-in corporate social responsibility (CSR). Using public and proprietary country-level sustainability and firm-level CSR data, we find that: (a) Legal origins are more fundamental sources of CSR than firms' financial performance; (b) The English common law, though widely-recognized as being most shareholder-oriented and economically efficient, fosters CSR and sustainability the least; (c) Political institutions-democratic rules and constraints to political executives-are not preconditions for CSR and sustainability, and sometimes even hinder CSR implementation; (d) Globally, CSR contributes to shareholder value maximization.
\end{abstract}

Keywords: Corporate social responsibility, sustainability, legal origins, political institutions, stakeholder orientation, shareholder value.

JEL Code: G30, K22, M14, O10, O57

\footnotetext{
${ }_{1}$ Both authors are from Tilburg University. We are grateful to Licht Amir, Lucian Bebchuk, Daniel Beunza, Fabio Braggion, Archie Carroll, Martijn Cremers, Hans Degryse, Magali Delmas, Elroy Dimson, Joost Driessen, Robert Eccles, Tore Ellingsen, Fabrizio Ferraro, Allen Ferrell, Caroline Flammer, Edward Freeman, Richard Friberg, Jesse Fried, William Goetzmann, Rebecca Henderson, Nancy Huyghebaert, Yannis Ioannou, Oguzhan Karakas, Thomas Lambert, Alberto Manconi, Chris Marquis, Mae McDonnell, Mark Roe, Amir Rubin, George Sefareim, Joaquim Schwalbach, Roy Shapira, Andrei Shleifer, Oliver Spalt, Holger Spamann, Sunny Li Sun, Jörgen Weibull, Nan Zhou, and the seminar participants at Harvard Law School, Harvard Business School, Tilburg University, University of Cambridge (Judge), Stockholm School of Economics, Humboldt-Berlin University, and University of Notre Dame (Mendoza), University Paris Dauphine, Norwegian School of Economics, as well as the conference participants to the $10^{\text {th }}$ and $11^{\text {th }}$ Corporate Finance Day (University of Ghent and University of Liège), EFMA 2014 Conference, ENTER Jamboree, and the Harvard Business School Conference on Sustainability and the Corporation: the Big Ideas, for helpful comments and suggestions. All errors are our own. Corresponding address: 5000 LE Tilburg, the Netherlands. Email: H.Liang@uvt.nl; Luc.Renneboog@uvt.nl
} 


\title{
Finance and Society: On the Foundations of Corporate Social Responsibility
}

\author{
"Business cannot succeed in a society that fails. Likewise, where and \\ when business is stifled, societies fail to thrive." \\ —Björn Stigson, World Business Council for Sustainable Development \\ "Driving shareholder wealth at the expense of everything else will not \\ create a company that's built to last." \\ —Paul Polman, CEO of Unilever, Harvard Business Review (2012)
}

Robert Shiller opens Finance and the Good Society by pointing to the potential tensions between financial development and the achievement of a good society that is characterized by a well-functioning capitalist system and democracy (2012: 1). The consensus in business and economics is that while financial development, which primarily depends on the protection of investor rights, does contribute to economic growth (King and Levine, 1993; Levine, 1997; Rajan and Zingales, 1998), a more fundamental issue is the sustainability—and not merely the growth—of economic development, which crucially hinges on the socially responsible operational and investment behavior of modern corporations (Porter, 1991).

What forces fundamentally steer companies to behave as good citizens in society, besides a profit maximizer? Is protecting stakeholder rights in conflict with protecting shareholder rights? What are the implications to societal sustainability? These are the key question of this study.

As our goal is to examine the foundations of CSR and how these foundations translate into economic sustainability, we start with defining CSR. We follow the classical economic perspective which considers CSR broadly as the private provision of public goods, which addresses the interests and needs of various stakeholders rather than that of investors who make financial claims, and is sometimes subject to laws and regulations. We define CSR as both a firm's engagement (voluntarily initiated) in and its 
compliance (legally mandated) to environmental, social, and governance (ESG) issues. This concept addresses concerns for the environment (such as climate change, hazardous waste, nuclear energy, ecological balance, etc.), society (social diversity, human rights, consumer protection, consumer consciousness, etc.), and corporate governance (management/board structures and representation, employee relations, executive compensation, anti-corruption measures, etc). ${ }^{2}$ The degree of CSR adoption should be determined both by the legal frameworks that define corporate boundaries, and by corporations' own tradeoff between shareholders' and stakeholders' rights.

Some scholars, such as Friedman (1970), Jensen (2001), and recently Cheng, Hong and Shue (2013), are skeptical about CSR and consider it a value-diverting activity that does not contribute to aggregate social welfare and sustainability. In this paper, we quantify the relationship between the firm-level CSR and the country-level sustainability relationship by showing that CSR scores are significantly correlated with country-level sustainability ratings in many dimensions. Some correlations are almost 30\% which is substantial given that the CSR scores and country sustainability ratings are from very different data sources and use different rating metrics. These significant correlations imply that CSR is closely linked to economic sustainability, which represents the preservation of resources and wealth. Although the focus in this paper is on firm-level CSR performance, we also refer to the country-level sustainability interchangeably throughout the rest of the paper, and aim to connect the determinants of CSR to the broader theme of economic development and social welfare.

The majority of the extant literature considers CSR as a firm's voluntary initiative, and relates it to the firm's financial and operational performance ('doing well by doing good'; e.g., Dowell et al., 2000; Orlitzky, Schmidt, and Rynes, 2003; Renneboog, ter Horst and Zhang, 2008, 2011; Guenster, Bauer, Derwall, and

2 Similarly, The European Federation of Financial Analysts Societies (EFFAS) interprets ESG as the need to focus on: (1) energy efficiency, (2) greenhouse gas emissions, (3) staff turnover, (4) training and qualification, (5) maturity of workforce, (6) absenteeism rate, (7) litigation risks, (8) corruption, and (9) revenues from new products. 
Koedijk, 2011; Cheng, Ioannou, and Serafeim, 2012; Deng, Kang, and Low, 2013). Others study the inverse, whether it is only well-performing firms that can afford to adhere to ESG criteria ('doing good by doing well'; e.g., Hong, Kubik, and Scheinkman, 2012). In addition, the extant studies usually take only one perspective of CSR, such as employee satisfaction (Edmans, 2011, 2012), environmental protection (e.g., Dowell, Hart, and Yeung, 2000; Konar and Cohen, 2001), corporate philanthropy (e.g., Seifert, Morris, and Bartkus, 2004), or consumer satisfaction (e.g., Luo and Bhattacharya, 2006; Servaes and Tamayo, 2013). Both the theoretical models and empirical evidence are rather ambiguous on the causal relationship between doing good and doing well (Margolis, Elfenbein and Walsh, 2007). If, apart from voluntary adoption, CSR is partly legally mandated, a single country study is not appropriate and one can only examine the fundamental determinants of CSR within a country-level institutional framework. Moreover, the classical public-private dichotomy also suggests investigating the driving forces of why corporations do social goods_-beside their financial responsibility and beside the governmental responsibility —at the institutional level. In fact, Doidge, Karolyi, and Stulz (2007) indeed find that country-level variation dominates firm-level variation in explaining firms' actual corporate governance practices. In this line, Ioannou and Serafeim (2012) empirically examine the association between "national institutions" and the scores on a CSR index although most of what they call "institutions", such as a leftist political ideology, ${ }^{3}$ are not true institutions with persistent and durable features in the spirit of North (1981), but rather the economic consequences of institutions (Glaeser, La Porta, Lopez-de-Silanes, Shleifer, 2004), which implies that those proxies for institutions may still be endogenously determined. This motivates to go one step further and think about the potential fundamental and latent (and thus other than financial and operational) determinants of CSR, especially

3 These variables include the measurement of regulations promoting competition, the level of corruption, leftist political ideologies, the power of labor unions, the availability of human capital, the presence of market-based financial systems, the existence of CSR stock market index, etc. In addition, the authors did not include legal origins, which we find in our paper are the fundamental determinants that can also simultaneously influence political and other outcomes. 
at the country-level.

The debates on the consequences and determinants of CSR reflect two conflicting "theories of the firm" (Williamson, 1981). The first theory views the firm as an internal relationship between owner and management (principal—agent relation), and suggests that the purpose of corporations is to maximize profits and shareholder value. The second theory focuses on the external relations between the firm and its stakeholders, and views the firm as a nexus of contracts between interested parties - in addition to shareholders, these comprise customers, suppliers, owners, managers, employees and communities (“stakeholders") — who realize economic gains through their participation in these contractual relationships. These two types of contractual relationship clearly reflect the potential tensions that Shiller (2012) describes between finance (shareholder orientation) and good society (stakeholder orientation) at the micro-level, and are both shaped by the macro-level institutional framework, which differs systematically across countries. It is widely believed that such systematic differences are due to countries' legal origins (e.g., La Porta, Lopez-de-Silanes, Shleifer, and Vishny [hereafter LLSV] 1997, 1998; La Porta, Lopez-de-Silanes, and Shleifer, 2008) and the political institutions (e.g., Rajan and Zingales, 2003; Pagano and Volpin, 2005; Perotti and von Thadden, 2006; Roe, 2003, 2006), which has a first-order effect on investor protection and financial development. In our context of CSR and good society, legal origins matter because they define how a society organizes rules to sustain prosperity at the macro-level, and to what extent shareholders and other stakeholders are protected at the micro-level (La Porta et al., 2008). Political institutions matter because they determine who possesses the political power to shape laws and regulations that benefit their political constituencies_-their stakeholders (Perotti and von Thadden, 2006). Therefore, we investigate the effects of legal origins and political institutions - which have been

4 The stakeholder perspective dates back to Edward Freeman's (1984) influential book Strategic Management: $A$ Stakeholder Aptroach. The book describes and recommends the methods by which management can give due regard to the interests of the stakeholder groups. Similar definitions and arguments can be found in Donaldson and Preston (1995), Mitchell, Agle, and Wood (1997), Tirole (2001), Friedman and Miles (2002) and Phillips (2003). 
documented to define finance and the contractual relationship of the firm—on CSR and sustainability.

By empirically testing these views, we find that the variations in CSR and sustainability are most fundamentally driven by legal origins, and not by political institutions or the well-documented financial and cultural motives. Surprisingly, we also find some evidence that institutional mechanisms that exclusively steer shareholder protection and financial development often fail to maximize stakeholder wealth and societal sustainability: among the different legal origins, the English common law fosters CSR the least, whereas the Scandinavian legal origin fosters it the most. Firms from German legal origin countries outperform their French counterparts in terms of ecological and environmental policy, but the French legal origin firms outperform German legal origin companies in social issues and labor relations. We also find that political institutions such as democracy that are believed to be a key determinant of access to finance are not preconditions for CSR and sustainability, and sometimes even hinder CSR implementation. Moreover, CSR is more encouraged in richer and more globalized countries and in corporations with more dispersed ownership and with co-determination. Finally, we find that protecting shareholder rights can be consistent with protecting stakeholder rights, and CSR can also reversely contribute to the maximization of shareholder value, as proxied by Tobin's Q, which imply that finance and a good society are not necessarily in conflict.

Our paper contributes in the following ways. First, while most cross-country studies on the role of fundamental institutions focus on country-level differences and use macro-level data that usually suffer from small sample inference and sensitivity to outliers, our unit of analysis is not only the country but also the firm for which we have extensive proprietary data on their performance on ESG issues, which also enable us to differentiate between CSR engagement and compliance. The fact that we combine a macroand micro-level analysis enables us to better understand the mechanisms of how fundamental institutions determine corporate behavior. Second, examining the potential tension between 
shareholders and stakeholders at the micro-level, as well as between financial development and societal sustainability at the macro-level, by directly testing the effect of one on the other, can suffer from endogeneity issue. Our approach circumvents this issue, as we investigate such tension by focusing on their common fundamental antecedents - the legal origins and political institutions - that are well established in economic theories. As we show in this paper, there are systematic differences at the institutional level, especially from legal origins, that fundamentally drive the divergence of shareholderand stakeholder-orientation across countries. Third, our study has policy and welfare implications: if institutional origins are found to be of first-order importance, then policymakers could imitate the tools associated with the winning origin. Hence, our empirical findings can offer a guide for institutional reform aiming at stimulating economic and societal sustainability. Many large corporations and countries worldwide today find it hard to achieve good citizenship and sustainable development, in part because of their institutional heritage.

The rest of the paper is organized as follows. Section I revisits the impact of legal origins and political institutions on corporate behavior and economic outcomes, and discusses their theoretical relevance to CSR and sustainability. Section II describes our data and empirical strategies. Section III exhibits the empirical results, while Section IV discusses the validity of alternative explanations and connects CSR to shareholder value. Section V concludes and formulates some policy implications.

\section{Institutional Origins, Finance, and Corporate Social Responsibility}

\section{A. Revisiting the Roles of Legal Origins}

The fundamental roles of legal origins on economic outcomes are advocated by LLSV $(1997,1998)$ and have been adopted by much of the subsequent law and finance literature. The legal origin theory argues that the largely exogenous legal origins—common versus civil law, and the legal subfamilies within the civil law tradition such as German, French, and Scandinavian legal systems—-set legal rules 
and their enforcement, which differ in terms of the priority to protect the rights of private investors vis-a-vis the state (Beck, Demirgüç-Kunt and Levine, 2003) and the mutual rights of different types of investors (shareholders versus creditors; majority versus minority shareholders). These differences form the bases of contracting and capital market development that are believed to be the foundations of financial and economic prosperity. Since the seminal work by LLSV (1998), it has almost become convention that the English common law system is globally superior to other civil law systems in protecting investor rights and facilitating desirable economic outcomes. ${ }^{5}$ There are two distinct views on the roles and effects of legal origins. The predominant view of legal origins - the "law and finance" view—rests on the principal-agent paradigm. Under this paradigm, corporate law aims to address the agency conflicts between managers and shareholders (under a dispersed ownership structure) and between controlling and minority shareholders (under concentrated ownership). The common law origin offers better protection for shareholders against corporate management, less state intervention in business activities, and more flexible judicial procedures. These advantages result in better market development which reduces the costs of external finance to firms and leads to more efficient capital allocation, and thus more economic prosperity (Rajan and Zingales, 1998). However, stakeholder rights are only vaguely defined under the principal-agent paradigm. Sacrificing profits to social interests can violate the shareholder primacy principle and the fiduciary duty embedded in company law, especially in common law countries. Protecting the interests of other constituencies is thought to be counterproductive and economically inefficient, as long as it cannot be explained by "enlightened shareholder value" (Gelter, 2009). Therefore, maximizing shareholder value is also maximizing social value, which is central to the principle of capitalism (Williamson, 1985).

5 However, the superiority of the common law has been questioned in some other studies. For example, Roe (2006) argues that the outperformance of common law countries in financial development is not due to legal origin, but due to the postwar legislatures and political ideologies. Spamann (2010) reconstructed the LLSV's legal data, and concludes that the superiority of the common law is not valid. 
In the alternative view — the stakeholder capitalism perspective — the company should be managed for the benefits and needs of all stakeholders, not merely its shareholders, in order to gain legitimacy in society (Freeman, 1984; Henderson and Ramanna, 2013). Purely focusing on the maximization of shareholder value does not necessarily lead to the maximization of social welfare in the long run, and could create large externalities and market failures. In the comparative corporate governance literature, the civil law traditions are more characterized by such stakeholder-orientation than the common law one (Matten and Moon, 2008). For example, in Germany, firms are legally required to also pursue the interests of parties other than only shareholders through the system of co-determination in which employees and shareholders have an equal number of seats on the supervisory board (Allen, Carletti, and Marquez, 2009). The harmonization laws of the European Community include provisions permitting corporations to take into account the interests of creditors, customers, potential investors, and employees. The corporate laws in Japan presume that Japanese corporations exist within a tightly connected and interrelated set of stakeholders, including suppliers, customers, lending institutions, and friendly corporations (Donaldson and Preston, 1995). Besides the shareholder-stakeholder tradeoff, legal origins are also the roots of a country's regulatory framework (Djankov, La Porta, Lopez-de-Silanes, and Shleifer, 2002), which more explicitly define which activities a company can legitimately engage in and which are strictly prohibited. Civil law countries are believed to have heavier regulation of economic activities, particularly those related to stakeholder welfare such as labor and environmental protection (Botero, Djankov, La Porta, Lopez-de-Silanes, and Shleifer, 2004).

Both views on legal origins are rooted in the shareholder-stakeholder tradeoff and have strong implications for CSR and sustainability. In addition to these debates on the fundamental roles of legal origins, many have argued that legal origin cannot fully explain the cross-country variation in economic outcomes, and ought to be complemented by an institutional view (e.g., Rajan and Zingales, 2003; 
Pagano and Volpin, 2005; Roe, 2006). Therefore, we review the political institutions as alternative origins of CSR in the next section.

\section{B. Revisiting the Roles of Political Institutions}

The prominent role of political institutions on economic outcomes_-in particular economic growth and financial development—have been advocated in recent years by Acemoglu et al. (2001, 2005), Easterly and Levine (2003), Rodrik, Subramanian, and Trebbi (2004), and Roe (2006). Political institutions refer to the set of rules such as democracy, electoral rules, legislative procedures, constraints to the political executives, etc. (North, 1981; LLSV, 1999; Glaeser et al., 2004; Roe, 2006; Matten and Moon, 2008). In our context, political institutions are an alternative pass-through from social preferences to business outside the framework of classical market interaction with firms (Kitzmueller and Shimshack, 2012). Democracy determines the distribution of power in society and how political institutions and mobilized interests aggregate preference. Countries that become democratic redistributed more to the society at large consisting of different stakeholders (Acemoglu, Naidu, Restrepo, and Robinson, 2013).

We also contrast two different views on political institutions: (1) the institutional view which regards political institutions, democracy in particular, as a pre-condition of economic outcomes, and (2) the development view which considers democratic participation as a consequence of economic development and modernization. The institutional view, often seen as 'conventional wisdom', considers good institutions as a fundamental determinant of welfare-enhancing economic outcomes (Acemoglu and Johnson, 2005). In the traditional political economy that embraces this view, political decisions are influenced by economic interests of overlapping stakeholders and voters (Kitzmueller and Shimshack, 2012). In particular, corporate stakeholders affect voters through corporate governance and decisions, which drive the creation and redistribution of national income and social welfare (Pagano and Volpin, 
2005; Perotti and von Thadden, 2006). Central to the political economy view is that the principal mode of political decision making is elections, and parties that win them shape laws that benefit their political constituencies (Botero et al., 2004). Here, the degree of democratic participation determines to what extent stakeholders can influence decision-making through political participation and voting for their representatives to implement the policies that protect their interests. The prevalence of democratic suffrage institutions and constraints on political elites facilitate broader access to finance (Barth, Caprio, and Levine, 2006) and helps protect property rights and investor rights (North and Weingast, 1989). Therefore, to foster CSR and achieve economic sustainability, good political institutions must come first: let people vote to influence their fortune, and to constrain the government from abusing power.

The development view on institutions is motivated by the modernization hypothesis of Lipset (1959) and the empirical evidence of Glaeser et al. (2004): institutional changes (such as democratization) result from economic development, and are thus a key component rather than a precondition of sustainability. The modernization processes, among which are modern corporations becoming more aware of social issues and more enthusiastic in providing public goods to deal with their externalities, create institutional change and lead the society to be more institutionally responsible. This then implies that key political institutions such as democracy do not precede CSR and sustainability. In addition, democratic participation represents differences in opinions due to voters' heterogeneous preferences on various social issues, which can create difficulties for consensus building (Allen, Qian, and Zhang, 2011). In a corporate context, this can be an impediment for innovation and may discourage socially-minded firms and managers from engaging in socially desirable but non-shareholder-oriented activities and hurt long-run incentives at the expense of stakeholders.

Several studies have analyzed how the macro-level political institutions shape the micro-level foundations of the tradeoff between shareholders' and other stakeholders' rights (e.g., Roe, 2003; 
Pagano and Volpin, 2005; Perotti and von Thadden, 2006; Perotti and Schwienbacher, 2009), though the scope of those analyses is limited to one specific group of stakeholders (for sample, the labor force), and one specific aspect of political institutions (for example, the electoral system and the preference of the median the voter), which arguably are not institutions per se. In the following sections, we empirically test the roles of the genuine institutions on firm-level CSR and country-level sustainability.

\section{Data and Empirical Strategy}

\section{A. CSR Data and Descriptive Statistics}

A variety of ESG indices is constructed by means of different rating methodologies (e.g. some based on a box-ticking approach—compliance, or on interpretative analysis — engagement) and hinges on various datasets, some of which are comprehensive and proprietary. We have extensively discussed the reliability of these ratings with practitioners, policymakers, and data providers. One could raise the concern that the "G" component of ESG measurement is overlapping with the traditional corporate governance issues which are materially different from the other stakeholder issues, as improving corporate governance does not necessarily require monetary investments while improving the welfare of other stakeholders does (Krueger, 2013). Therefore, we have deliberately selected databases that minimize the weight on corporate governance regulation, while giving more emphasis on environmental and social issues.

Our main data on ESG performance are from MSCI's Intangible Value Assessment (IVA) database. The IVA indices measure a corporation's environmental and social risks and opportunities, which refer to issues where companies in a certain industry currently generate large environmental and social externalities and may be forced to internalize unanticipated costs associated with those externalities in the future. The rating then takes into account the extent to which a company has developed robust strategies and demonstrated a strong track record of performance in managing these specific risks and opportunities. 
Such rating methods capture both the legally mandated aspects (unanticipated costs associated with regulatory penalties and lawsuits) and voluntary aspects (risk management strategies and strategies to capture potential opportunities) of CSR. An important note is that companies are rated and ranked in comparison to their industry peers from both domestic and international markets, and therefore the rating does not depend on the local CSR situations and rules. The IVA Rating is compiled using company profiles, ratings, scores, and industry reports, and is available from 1999 to $2011 .{ }^{6}$ Its coverage comprises the top 1,500 companies of the MSCI World Index (expanding to the full MSCI World Index over the course of the sample period); the top 25 companies of the MSCI Emerging Markets Index; the top 275 companies by market cap of the FTSE 100 and the FTSE 250 (excluding investment trusts); and the ASX 200. For this large sample with global coverage, MSCI constructs a series of 29 ESG scores ${ }^{7}$, among which, Labor Relations, Industry Specific Carbon Risk, and Environmental Opportunity receive the highest weights in the global rating, and the weight on traditional corporate governance regulation is below $2 \%$. The detailed composition of the IVA rating is shown in Table 1. Furthermore, we complement the IVA ratings from MSCI with the Risk:Metrics EcoValue21 Rating and the Risk:Metrics Social Rating from RiskMetrics and so capture the environmental and social aspects of CSR, respectively.

[Insert Table 1 about here]

\footnotetext{
6 The information on which the IVA ratings are based is extracted from the following sources: (a) Corporate documents: annual reports, environmental and social reports, securities filings, websites, and Carbon Disclosure Project responses; (b) Government data: central bank data, U.S. Toxic Release Inventory, Comprehensive Environmental Response and Liability Information System (CERCLIS), RCRA Hazardous Waste Data Management System, etc. In particular for European companies, the information is expanded by means of many other information sources; (c) Trade and academic journals included in Factiva and Nexis; and (d) professional organizations and experts: reports from and interviews with trade groups, industry experts, and non-governmental organizations familiar with the companies' operations.

7 A key ESG issue is defined as an environmental and/or social externality that has the potential to become internalized by the industry or the company through one or more of the following triggers: (a) Pending or proposed regulation; (b) A potential supply constraint;(c) A notable shift in demand; (d) A major strategic response by an established competitor; (e) Growing public awareness or concern. Once up to five key issues have been selected, analysts work with sector team leaders to make any necessary adjustments to the weights in the model. Each key issue typically comprises $10-30 \%$ of the total IVA rating. The weights take into account the impact of companies, their supply chains, and their products and the financial implications of these impacts. For each key issue, a wide range of data are collected to address the question: "To what extent is risk management commensurate with risk exposure?"
} 
Our main sample covers 91,373 firm-time observations from 59 countries. By means of the Standard Industrial Classification (SIC) and the Kompass sector classification, we classify our sample firms into 17 aggregated industries We also employ other CSR indices provided by various ESG rating agencies with a global scope in order to validate our results. These indices include MSCI's Impact Monitor data, Vigeo’s corporate ESG ratings, and Thomson Reuters' Asset4 ratings of which the country coverage and number of observations are shown in Appendix. In contrast to the MSCI IVA data that focus on engagement (developing strategies to manage its risks and opportunities), the Vigeo ESG data is more CSR compliance-oriented as it applies a check-the-box approach to rate how a firm and the country in which it operates comply with the conventions, guidelines, and declarations by international organizations such as UN, ILO, and OECD. We also obtain a cross-sectional dataset of country-level sustainability ratings from Vigeo, which rates each country based on the laws and regulations that fulfill the country's (1) environmental responsibility, (2) social responsibility and solidarity, and (3) institutional responsibility, which is a country's legal and regulatory framework in relation to sustainability. These three country-level domains echo the firm-level "E", "S" and "G" criteria. ${ }^{8}$

\section{B. Methodology}

As the IVA ratings measuring a company's ESG performance are integers ranging from 0 to 6 and are not normally distributed but, we use the nonparametric Wilconxon-Mann-Whitney test in a univariate analysis which compares the median ESG values across different legal origins, and between capitalist and socialist countries. We will subsequently apply reduced-form regressions to analyze the impact of legal origin and political institutions on CSR. Given that some of our independent variables

8 The sovereign ratings are based on 120 ESG risk and performance indicators in the aforementioned three domains. Countries are graded on a scale of 100 on their commitment and performance in these indicators such as ratification of the Kyoto convention, the Vienna convention, the Stockholm convention, CO2 emissions per head, Gini index, etc. 
are time-invariant (e.g., legal origins) and that we would like to draw inferences on the population, random-effect models are most suitable in this panel setting. Our estimations are made by OLS, random-effect generalized least squares (GLS), and random-effects ordered probit models. The last are estimated by means of maximum likelihood and considers the discrete, ordinal nature of the ratings and the rating changes in a panel data set (as in e.g., Alsakka and Gwilym, 2010). The general specification can be expressed as:

$$
y_{i t}^{*}=\alpha_{t}+\beta_{1}^{\prime} \text { Legal }_{c}+\beta_{2}^{\prime} \text { Political }_{c t}+\beta_{3}^{\prime} X_{i t}+\gamma^{\prime} Z_{\mathrm{ct}}+\delta_{i t}
$$

Where Legal is a vector of different types of civil law origins, Political is a vector of political institutions which, in our sample, are mostly time-variant, $X_{i t}$ is the vector of firm-level financial and governance variables, while $Z_{\mathrm{ct}}$ is a vector of country-level control variables. Except for legal origins, all the other variables are time-variant in nature, making firm-time random-effect models most suitable. The subscript $i$ refers to the individual firm, $t$ to the time, and $c$ to the country. $y_{i t}^{*}$ is the firm-level ESG rating. In the case of ordered probit models, $y_{i t}^{*}$ is an unobserved latent variable linked to the observed ordinal response categories $y_{i t}$ :

$$
y_{i t}=\left[\begin{array}{rr}
0 & \text { if } y_{i t}^{*} \leq \mu_{1} \\
1 & \text { if } \mu_{1}<y_{i t}^{*} \leq \mu_{2} \\
2 & \text { if } \mu_{2}<y_{i t}^{*} \leq \mu_{3} \\
3 & \text { if } \mu_{3}<y_{i t}^{*} \leq \mu_{4} \\
4 & \text { if } \mu_{4}<y_{i t}^{*} \leq \mu_{5} \\
5 & \text { if } \mu_{5}<y_{i t}^{*} \leq \mu_{6} \\
6 & \text { if } \mu_{6}<y_{i t}^{*}
\end{array}\right]
$$

The $\mu^{\prime} s$ represent thresholds to be estimated (along with the $\beta$ and $\gamma$ coefficients) using maximum likelihood estimation, subject to the constraint that $\mu_{1}<\mu_{2}<\mu_{3}<\mu_{4}<\mu_{5}<\mu_{6}$.

\section{The Variables}

In equation (1), the dependent variables are various CSR measures that capture the different dimensions of firms' engagement and compliance to ESG issues. In addition to the global IVA Rating, 
we also use the main sub-indices (those which enter with the highest weights in the global index), namely Labor Relations, Industry Specific Carbon Risk, and Environmental Opportunity, as regressands. Furthermore, we re-estimate our models using RiskMetrics EcoValue21 Rating and the RiskMetrics Social Rating (both are converted to ordered integer scores ranging from 0 to 6 ) as additional dependent variables. As explanatory variables, we include:

Legal Origins

The legal origin refers to the type of law that applies in the country where the firm is headquartered: English common law, French/German/Scandinavian civil law systems, and Socialist origins (both current and former socialist countries) (LLSV, 1998).

\section{Political Institutions}

To capture the existence of political institutions, we define the variable Democracy. While democracy is a term comprising many different aspects, Glaeser et al. (2004) argue that only aspects that directly relate to electoral rules are a good proxy for "institutions". Therefore, we mainly focus on indices that measure democratic participation and rules that define voting and elections: the Polity IV Democracy index and Vanhanen Democracy index which are often used in political economy.

Political Executive Constraints proxies for the constraints to potential expropriation by the political elites, which is also suggested by Glaeser et al. (2004): "Political executive constraints] is the only measure that is clearly not a consequence of dictatorial choices, and [...] can at least loosely be thought of as relating to constraints to government" (p. 282). We use the same index, developed by Polity IV.

Our third political variable is Corruption Control which measures the extent to which politicians are constrained from pursuing their self-interest (through corruption), and to some extent also captures "constraints". Since it also measures the "benevolence" (lack of corruption) of the government, combining it with the democracy variable contributes to the interpretation of the results on democracy. 
We also control for corporate governance structures such as the nature and dispersion of ownership and board structures, as they matter for the balance of power between shareholders and other stakeholders.

Ownership Dispersion is directly influenced by legal origins and political institutions (Aslan and Kumar, 2012; Roe, 2003, 2006), but may at the same time affect the protection of stakeholder rights. The literature highlights both the negative consequences of dispersed ownership due to managerial agency problems, and its positive value implication due to the alleviation of dominant shareholder problem (as dominant shareholder can expropriate the right of minority shareholders). Ownership dispersion also captures the extent to which conflicts can arise between shareholders and stakeholders regarding CSR expenditures (Barnea and Rubin, 2010). We use the Orbis' Independence Indicator as a proxy for ownership dispersion/concentration.

Ultimate Owner Types include (i) the state; (ii) wealthy individuals or families; (iii) foundations or research institutes (e.g. universities); (iv) pension funds; (v) venture capital and private equity; (vi) banks, insurance companies and other financial institutions (financial consortia); and (vii) corporations (Claessens, Djankov, and Lang 2000). Economic theories have ambiguous predictions of the impact of different type ultimate owners on CSR. For example, while the public interest theories favor state-owned firms in bearing more social responsibilities to solve market failure, the public choice view posits that state-owned firms can expropriate private firms through distorting resource allocation and rent-seeking (Fogel, Morck, and Yeung, 2008). Similarly, while some view family firms as being long-term oriented and caring about the relationship with communities (e.g., Anderson and Reeb, 2003), others argue that family firms can extract rents from other investors through various control mechanisms, which retard economic development (Morck, Wolfenzon, and Yeung, 2005). A similar tradeoff applies to the role of 
institutional investors, as on one hand they exert shareholder activism to promote CSR (Dimson, Karakas, and Li, 2012), while on the other hand they have a short-term investment horizon and favor ownership stakes in firms with high trading liquidity from which exit can take place quickly.

The board of directors' Tier Structure refers to the adoption of a one-tier board system that combines the management and supervisory directors into one body, or a two-tier system that separates them. Under the two-tier structure, the supervisory board usually consists of employees and outsiders, which fosters codetermination between shareholders and other stakeholders. In about three quarters of the countries, the one-tier board has been legally or voluntarily adopted. Elsewhere, notably in Germany, the Netherlands, Austria and Scandinavia, the two-tier structure prevails. We include a firm-level dummy variable capturing the existence of a supervisory board.

We also include a set of control variables such as firm-level financial constraints to investigate whether firms are "doing good by doing well" (Hong, Kubik, and Scheinkman, 2012). Our variables capture different aspects of financial constraints: (1) short-term investment to cash flow sensitivity (Fazzari, Hubbard, and Petersen, 1988), (2) interest coverage, and (3) financial slack, measured by the current ratio. We also include financial performance: return on assets (ROA).

\section{Country-level Controls}

We control in equation (1) for a country's level of economic development: the (logarithm of the) GDP per capita and a globalization index. GDP per capita captures income and wealth effects, as people in richer countries are more likely to care about sustainability while those in poor countries merely worry about daily economic survival. The globalization index is expected to capture the spillover effect of CSR standards across countries, as corporations in more globalized countries are under higher pressure to comply with international conventions and principles that outline the norms for acceptable corporate social conduct. Detailed definitions and sources of all our variables are summarized in Appendix. 
We control for industry and year fixed effects in the GLS models to (partially) take unobserved heterogeneity into account, but not for country fixed effects given the time-invariance of some key variables. We cluster the standard errors at the country level. In unreported regressions, we cluster the standard errors also at the firm level which yields similar (and stronger) results. Finally, as legal origins and political institution precede the emergence of CSR and are not likely to be reversely affected by CSR, ${ }^{9}$ our results do not suffer from endogeneity problems.

\section{Results}

\section{A. Descriptive Results}

We first examine the relation between firm-level CSR (the CSR ratings from MSCI IVA) and country-level sustainability (the Vigeo sustainable country ratings). The average correlation coefficient between these two sets of indices is above $25 \%$ and statistically significant at the $99 \%$ level. The correlations between the aggregated IVA rating and the overall country rating, the environmental responsibility country rating, the institutional responsibility country rating, and the social responsibility and solidarity country rating amount to $29 \%, 21 \%, 28 \%$ and $26 \%$, respectively. The correlations between the RiskMetrics Ecovalue rating and the aforementioned country ratings are 23\%, 24\%, 21\% and 20\%, respectively. The correlations between the RiskMetrics Social rating and those country ratings are 26\%, $20 \%, 25 \%$ and $24 \%$. Given that two datasets are from different sources and are constructed by means of different rating metrics, the positive correlations are remarkable. It confirms the aforementioned normative argument that CSR is closely related to societal sustainability, and indicates that the fact that firms address social/environmental/governance issues is not mutually exclusive to governmental efforts to achieve a sustainable society.

We compare the mean ESG ratings for the countries belonging to different legal origins in Table 2.

9 Although in some countries, large corporations can influence regulation and politics through lobbying, such influence is on the outcome of institutions, not on the democratic institutions per se. 
In addition to the overall ESG rating (Overall IVA Rating) and two general ratings on environmental and social policies (EcoValue21 Rating and Social Rating), we also show the various components of the CSR subcategories representing benefits for different types of stakeholders. ${ }^{10}$ The comparisons of the means of the CSR indices across legal origin in Table 2 show that the English common law system is inferior to the civil law systems in terms of fostering good corporate ESG performance. Firms from the Scandinavian and German legal origins outperform those from the English common law system, especially in terms of environmental issues, as indicated by the scores in EcoValue21 Rating and the subcategories Environment, Environmental Management Capacity, Environmental Opportunity, Industry Specific Carbon Risk, Environmental strategy, Environmental Management Systems, Environmental Accounting Reporting, Certification (e.g., ISO14000), etc. In social- and labor-related issues, firms from the French legal origins outperform those from the English and German legal origins, as can be derived from the scores of the Social Rating and the subcategories Human Capital, Stakeholder Capital, Employee Motivation and Development, Labor Relations, Health Safety, Customer Stakeholder Partnerships, Human Rights Child and Forced Labor, etc. The English common law system is only superior to civil law systems in the domain of the firm's interactions with local communities and traditional corporate governance concerns. Companies from the Socialist legal origin perform the worst across the board.

\section{[Insert Tables 2 about here]}

Countries differ significantly in terms of the average ESG rating of their companies. For example, the average IVA rating of Irish companies is 1.89 while the average of Swedish companies is 4.19 (on a

10 For example, the CSR benefits for shareholders and creditors can be inferred from Strategic Governance, Strategic Capability \& Adaptability, Traditional Governance Concerns, etc. The benefits for employees - the recognition of human capital - are manifested in Employee Motivation Development, Labor Relations, Health \& Safety, etc. The benefits for customers can be derived from the categories Customer Stakeholder Partnerships, Intellectual Capital \& Product Development, Product Safety, etc. The environmental issues - categories Environmental Management capacity through (Environmental) Performance - are crucial to all types of stakeholders. 
scale of 7), though both Ireland and Sweden are economically and culturally not dissimilar. This implies that there is a substantial cross-country variation, which is not reflected in the countries' and firms' geographical and economic indicators, ${ }^{11}$ and should instead be captured by the countries' legal origins (La Porta et al., 2008). Therefore, we also investigate the differences across legal origins for various aspects of CSR using a non-parametric test (Wilcoxon-Man-Whitney test). Table 3 shows that the differences in ESG performance (overall and by component) are highly statistically significant across legal families, and that civil law countries consistently outperform common law countries in all ESG subfields. Within the civil law countries, we find that firms of countries with German legal origin outperform their French counterparts in terms of ecological and environmental policy (EcoValue 21 rating, Industry Specific Carbon Risk, and Environmental Opportunity), but that the French legal origin firms outperform German legal origin companies in social issues and labor relations. Capitalist economies attach more attention to ESG relative to the current and former socialist countries (Russia, China, and some Eastern European countries).

\section{[Insert Table 3 about Here]}

\section{B. ESG Models}

In Table 4 we present the results from random-effect GLS models explaining the variation in the overall IVA rating. The English common law origin is our benchmark and is therefore omitted from the models. ${ }^{12}$ Model (1) shows the results from regressing the IVA rating on the country-level variables only: legal origins, the Polity IV democracy index, the logarithm of GDP per capita and the globalization index. In Model (2), we add Corruption Control, the firm-level ownership dispersion index, the board's

\footnotetext{
11 For example, Ireland and Sweden have similar GDP per capital, geography, latitudes (North-west Europe), and living standards, and Irish and Swedish firms have similar market-to-book ratios, financial constraints, dividend payout ratio, and other financial performance indicators.

12 Given the consistent ESG underperformance of firms in (current or former) socialist countries, which are still under an autocratic or dictatorial regime, we exclude these countries from our sample, and focus on the differences between common law systems and civil law systems (and their subsystems).
} 
tier-structure dummy, financial control variables (financial performance and slack), and year fixed effects. In Model (3), we replace Democracy and Corruption Control by Executive Constraints (following Glaeser et al., 2004) $)^{13}$, and cluster the standard errors at the firm-level (rather than at the country-level). We further expand Models (4) and (5) with the types of ultimate owner (whereby the case in which industrial companies are the ultimate owners is the benchmark) and industry fixed effects. ${ }^{14}$ Model (6) has the same specification as Model (5), except that it is estimated by means of a pooled OLS.

Several important observations can be made: First, the coefficients on the French, German, and Scandinavian civil law origins from models (1) to (6) are almost all positive and statistically significant, implying that firms under civil law systems do better in terms of ESG adoption/performance than those under the English common law system. The economic significance is also nontrivial: compared with the English common law origin, companies in countries with Scandinavian civil law outperform by about one grade of the ESG rating in the random-effects model (and by more than 2.5 grades in the pooled OLS model). Similar economic magnitudes are found for French and German legal origins. This contrasts with the law and finance literature: when it comes to shareholder protection, the common-law countries generally have the strongest, and French civil-law countries the weakest investor protection and financial development (LLSV, 1998). Our findings echo the stakeholder view on legal origins: while common law focuses more on the legal protection of shareholders which are the premise of stronger financial development, it largely neglects the rights of a broader stakeholder group.

Second, in Models (1)-(3), none of the coefficients on political institutions-captured by democracy (the Polity IV democracy index), corruption control and the executive constraints—are

\footnotetext{
13 We do not include the Polity IV democracy index and the Executive Constraints index in the same regression as they are strongly correlated $(96 \%)$. In the Polity IV definition, "executive constraints" is part of the democracy index. 14 In Model (5), we further exclude Financial Constraints measured as the sensitivity of short-term investment to cash flow, considering Chen \& Chen's (2012) criticism on this measure. We also exclude Financial Slack (current ratio) - a measure of liquidity and the ability to meet creditors' demand - which is sensitive to the type of ultimate owner. Given that not all firms have dominant shareholders as the ultimate owner, the number of observations declines (if a company does not have ultimate owner, the observations for the UO variable are treated as missing values).
} 
statistically significant, even when standard errors are clustered at the firm-level (as in Model (3)). In Model (4), the democracy variable is now the Vanhanen's democracy index ${ }^{15}$ and we add the ultimate owner types. We show that the coefficients on democracy and executive constraints remain insignificant, although the one on corruption control is positive and significant. These findings are in line with the development view on political institutions in that a higher degree of democracy does not necessarily lead to more CSR adoption or higher CSR performance. In particular, due to its complex nature and difficulty in consensus building, democratic participation in political decision making may be a burden for corporations' fulfillment of social responsibilities, especially those voluntary initiatives which are often beyond laws and regulations, and discourage socially-minded managers from engaging in such activities. ${ }^{16}$ However, we tend not to interpret the negative coefficient on Democracy as unaccountability of the democratic process on ESG issues, but we emphasize the inefficiency of the democratic participation process in dealing with changes in ESG preferences. This is consistent with many empirical findings (e.g. Barro, 1996; Rodrik, 1999) that economically free but politically repressed countries tend to achieve more rapid growth. It is also in line with Glaeser et al. (2004) in that democratic institutions do not cause growth and create wealth; rather, they are the consequence of economic growth. Our findings may contribute to these arguments and further suggest that democratic institutions, though they affect corporate governance and decisions which arguably drive wealth distribution (Perotti and von Thadden, 2006), do not function to sustain wealth. In addition, a country's economic development-GDP per capita and globalization - is mostly positively, but not consistently correlated with CSR, which echoes the arguments by Ioannis and Serafeim (2012).

For the firm-level variables, Table 4 also shows that co-determination, as captured by the presence

15 The Vanhanen Index is taken for 2000, the initial year of data available for most companies in our sample.

16 In unreported regressions where we include all ultimate owner dummies and treat "no ultimate owner" as the base case, the main results on legal origins and political institutions remain unchanged. 
of a separate supervisory board (a two-tier board structure, which is largely legally mandated in civil law countries), is related to a higher CSR score. Controlling shareholders-the state, individuals or families, financial institutions, pension funds, and private equity—do not positively affect ESG performance. Furthermore, most of the financial performance and constraints variables are statistically insignificant, indicating they are not the primary source of CSR. This finding fails to support the 'doing good by doing well' hypothesis, in that more profitable and less financially constrained firms are able to assume more social responsibilities (Hong et al., 2012).

\section{[Insert Table 4 about Here]}

To further examine the effects of legal origins and political institutions on different aspects of CSR, and to evaluate the nuanced cross-country differences that stem from corporate choices and from governmental regulations, we take as dependent variables: the RiskMetrics' EcoValue21 Rating and Social Rating (both are ordinal integer scores ranging from 0 to 6 ), and the components receiving the highest weights in the IVA index: Labor Relations, Industry Specific Carbon Risk, Environmental Opportunity (which are ordinal integer scores ranging from 0 to 10). For each dependent variable, we report in Table 5 the results from random-effect GLS models with specifications similar to those of Table 4. In line with earlier results, we document that the coefficients on the three civil law dummies are mostly positive and statistically significant. This further reinforces the argument that companies in countries with civil law origins outperform those with the common law origin in terms of engagement in environmental issues (including industry-specific carbon risk) and social (including labor relations) aspects. In terms of ecology, companies from all the three civil law origins outperform common law firms by almost one index grade on average. In areas related to social issues and labor relations, companies from the civil law origins still mostly outperform common law firms. "Labor Relations" captures corporate compliance to issues typically regulated by labor laws. Therefore, it is intuitive that civil law countries do better than 
common law countries on this issue since labor laws are generally more favorable to workers. Similar results and arguments apply to "Industry-Specific Carbon Risks" which relate to carbon emissions, as civil law countries generally have stricter government interventions and regulations (Djankov et al., 2002; Botero et al., 2004). Interestingly, in terms of exploring "Environmental Opportunities", which clearly stems from firm choices (e.g., investing in $\mathrm{R} \& \mathrm{D}$ and developing product differentiation strategies), civil law countries still on average outperform common law countries. In addition, the coefficients on democracy and executive constraints are mostly insignificant. The presence of a two-tier board is positively and significantly related to the firm's ESG performance. In most cases, controlling shareholders do not play a positive role in ESG engagement, except for companies that are ultimately controlled by non-for-profit organizations such as foundations and research institutes (who can adopt a stakeholder approach). The coefficients on ROA and financial slack (current ratio) are mostly negative and the one on financial constraints are mostly insignificant, which confirms that there is no support for the doing good by doing well hypothesis. All in all, the conclusions for the overall CSR index (Table 4) are valid for the specific ESG indices of Table 5. In unreported regressions, we test the same specification on all the 29 sub-scores that constitute the overall IVA index, and get the similar results for most of these sub-scores. This suggests that our previous findings are consistent rather than being driven by the uneven weights of certain factors in the index.

\section{[nsert Table 5 about Here]}

\section{Robustness}

\section{C.1. Random-effects ordered probit models}

Since we use ordinal dependent variables, we re-estimate the above models by means of random-effects ordered probit models ${ }^{17}$. The first three columns (Models (1)-(3)) in Table 6 report the

17 Given the complex nature of our non-linear estimation models, we cannot add in all the possible explanatory 
results when we only include legal origins in the models with IVA Rating, EcoValue21 Rating and Social Rating as the dependent variables, respectively. Similar to the GLS results of Tables 4 and 5, the coefficients on the three civil law origins are mostly positive and statistically significant at the $99 \%$ confidence level (with exception of the French origin in environmental performance and the German origin in social performance). As before, the economic significance of the Scandinavian origin remains the highest across the civil law origins: Scandinavian origin increases the ESG rating by over 2 grades relative to the English origin. Models (4) - (6) of Table 6 show the results of further including political institutions as well as other country- and firm-level covariates. We use Executive Constraints—suggested by Glaeser et al. (2004) and Acemoglu and Johnson (2005) — as our key proxy for political institutions. Again, our results on legal origins are upheld and the sign on Executive Constraints remains negative. ${ }^{18}$

\section{[Insert Table 6 about Here]}

\section{C.2. Alternative democracy indices}

The negative relation between CSR scores and our two indices on democratic participation (the Polity IV democracy index and the Vanhanen index) might seem counter-intuitive under the institutional view. To check the robustness of the previous results on political institutions (democracy), we try several other democracy indices that measure similar aspects of political participation and democratic rule: the Democracy Ranking, the Economist Intelligence Unit's (EIU) Democracy Index (both the overall EIU democracy index in 2006, and the EIU index of electoral rules and political participation over different years), the Free House Political Rights Index, the Unified Democracy Scores, and the Polyarchy

\footnotetext{
variables as they sometimes may not result in convergent estimations, and need to make some choices. We do not include the ultimate owner type in the estimation as these dummy variables account for only a small portion of the sample and including them will lead to non-convergence in the estimation. We also exclude the globalization index from all models, and include Corruption Control in Model (4), for the same reason. In addition, the firm-level Supervisory Board dummy is replaced by a country-level Board Tier Structure variable (see definition in Appendix) for convergent estimations.

${ }_{18}$ Regulatory Quality, although not strictly a measure of institutions per se, is used as a control variable to help reach convergent estimations. A positive sign of regulatory quality, as in Model (4) and (5), should indicate the importance of government regulations on stakeholder protection from state expropriation.
} 
Democracy Index 2000 (for definitions see Appendix). The previous results survive (not reported) with different democracy indices: Legal origin remains to be the most persistent determinant of CSR, and firms with civil law origins outperform those with the common law origin in ESG terms; and different democracy indices are either insignificantly or negatively associated with various CSR ratings which is congruent with the development view of institutions.

\section{C.3. Alternative CSR data}

One could be concerned that our empirical results are driven by the peculiarity of our CSR data.

The similarity in the results from the MSCI IVA data and from RiskMetrics data (EcoValue21 Rating and Social Rating) could be due to the fact that they use similar rating methodologies. ${ }^{19}$ To address this issue, we conduct our tests on CSR scores from other databases with global coverage: (i) the ESG Impact Monitor, ${ }^{20}$ (ii) Vigeo's corporate ESG (panel) data, ${ }^{21}$ and (iii) Thomson Reuters' Asset4 (panel) data. ${ }^{22}$ We examine three additional stakeholder-oriented dimensions from the Vigeo database which measures corporate compliance rather than engagement related to human resources, consumer \& supplier relations, and human rights. We use both the Vanhanen democracy index and the Polity IV democracy index to capture the impact of institutions, and we also in- and exclude the variable Corruption Control as a robustness check. Table 7 shows that that our previous results largely survive with different ESG measures from the above alternative CSR databases: firms with civil law origins outperform those with common law origin in terms of CSR. The exception is in Model (3) but the reverse (negative) signs on

19 RiskMetrics/ISS was acquired by MSCI in 2010, although their original rating methodologies have been maintained. 20 Also developed by MSCI but with emphasis on the 'impact' of companies' ESG performance (especially on the significance of a company's social and environmental impact and its ability to manage that impact). The database captures how well a company adheres to international norms and principles such as the UN Global Compact and ILO Core Conventions and assesses corporate strategies, disclosure and performance with respect to these norms and principles. The dataset is cross-sectional (no repeated firm observation in consecutive years).

21 ESG performance focusing on six domains: (1) environment, (2) human rights, (3) human resources, (4) business behavior (customers \& suppliers), (5) community involvement, and (6) corporate governance.

22 ESG information on 4,300+ global companies based on $250+$ key performance indicators and $750+$ individual data points covering every aspect of sustainability reporting. The sample includes MSCI World, MSCI Europe, STOXX 600, NASDAQ 100, Russell 1000, S\&P 500, FTSE 100, ASX 300 and MSCI Emerging Market. On average, 10 years (from 2002) of history is available for most companies. 
legal origins are still not that unexpected because the Vigeo corporate governance dependent variable measures the traditional governance concerns from agency perspective. The fact that firms with common law origins do better in terms of shareholder protection is indeed consistent with the traditional law and finance view. In terms of compliance to human resources rules, firms under civil law do better than those under common law (Model (4) of Table 7), but in the domain of consumer and supplier concerns, only firms under Scandinavian legal origin outperform (Model (5)). Concerning human rights (Model (6)), the French origin is superior to the common law. In addition, the sign of the coefficient on the democracy index is still persistently either negative or insignificant.

\section{[Insert Table 7 about here]}

A statistical issue for our analysis is that some of our country- and firm-level variables are endogenously affected by CSR (“doing well by doing good”). To address this concern, we apply an instrumental variable approach in the spirit of La Porta et al. (2008) by using legal origins and political institutions as instruments for GDP per capital, ownership and board structures, financial constraints and profitability in a two-stage procedure, where the second stage explains CSR performance. In unreported results, the above findings are still upheld, though they should be interpreted with caution as legal origins and political institutions may influence CSR through other channels. In addition, we repeat our analysis for the countries in our sample that are former colonies, whose legal origins are absolutely exogenous. All our results survive and, if anything, become stronger.

One may be concerned about the weighting of countries by the number of their firm-years in the data by using random effect models. We therefore construct a new sample consisting of the ten largest companies in terms of market capitalization in each country (countries with fewer than ten companies are dropped). ${ }^{23}$ In unreported regressions, we conduct OLS tests on this equally-weighted sample with

23 This leaves us with 32 countries and 320 observations if we run simple OLS, or 8,916 observations if we run 
the same variables, and the previous main results still survive. We also conduct OLS tests on the determinants of sustainability at the country level, as shown in Section IV, which give similar results.

In sum, our empirical results suggest that the countries with an English common law origin do not foster CSR adoption — neither in terms of engagement nor compliance-as much as the civil law countries. Democratic institutions and executive constraints do not seem to be fundamental determinants of CSR, and often even slow CSR adoption and performance down. Furthermore, ownership dispersion and a two-tier board structure are often positively associated with CSR implementation, but financial performance is not.

\section{Alternative Explanations}

\section{A. Investor protection}

We also investigate whether the impact of legal origins on CSR occurs through corporate governance rules. Presumably, legal origins can have a direct impact on CSR through the shareholder-stakeholder tradeoff (embedded in the spirit of law), or an indirect one through rules and regulations related to investor protection and corporate governance. Therefore, we include in our models several investor protection indices: (i) the anti-director rights index (ADRI), ${ }^{24}$ (ii) the MartynovaRenneboog (2011) (M-R) corporate governance regulation index on minority shareholder protection (developed for 30 European countries and the US and is time-variant), (iii) the anti-self-dealing index (ASDI) introduced by Djankov et al. (2008), (iv) the public enforcement index introduced by Djankov et al. (2008), and (v) the one-share one-vote index that was first introduced in LLSV (1998) and then adjusted by Spamann (2010). We then regress the corporate ESG ratings on the investor protection

random effects or pooled OLS.

24 Both the original LLSV (1998) ADRI and Spamann's (2010) revised ADRI consist of six key components: (1) proxy by mail allowed; (2) shares not blocked before shareholder meeting; (3) cumulative voting/ proportional representation; (4) oppressed minority protection; (5) preemptive rights to new share issues; and (6) percentage of share capital to call an extraordinary shareholder meeting. 
indices, legal origins (as in Spamann (2010)), and the Polity IV democracy/Vanhanen index, along with other control variables. In most specifications shown in Table 8, the results on legal origins remain valid, and the coefficients on investor protection indices (ADRI, M-R minority protection index, ASDI) are positive and statistically significant. This signifies that CSR adoption is consistent with different degrees of investor protection, especially the protection on minority shareholders.

[nsert Table 8 about here]

\section{B. Culture}

As culture could have affected both legal origins and political institutions, and have an impact on CSR performance, we control for culture by introducing the widely-used Hofstede five cultural dimensions at the country level (Hofstede and Hofstede, 2005). These dimensions are: (1) power distance, (2) individualism, (3) masculinity/femininity, (4) uncertainty avoidance, and (5) long-term orientation (for definitions see Appendix). We present the tests in Table 9: as culture and economic performance are usually endogenously determined (Stulz and Williamson, 2003; Sapienza, Zingales, and Guiso, 2006; Tabellini, 2010), we exclude the two economic development variables, Ln(GDP per capita) and the globalization index. While our previous results on legal origins, democratic participation and political executive constraints, as well as ownership and board structures are maintained when we include a set of culture variables, the effect of culture per se on CSR is not strong or consistent. We must conclude that culture, in contrast to legal origin, is not a good predictor of CSR performance.

[Insert Table 9 about here]

\section{Country-level Sustainability}

We further run simple OLS regressions at the country-level. We relate the Vigeo sustainable country ratings (175 countries worldwide) to the country-level variables used in the above analyses: legal origins, political institutions, economic development variables, and ADRI. The findings in Table 10 
suggest that: (1) Legal origins strongly explain the variation in countries' sustainability measures—the overall score, specific ratings for the environment, social issues and solidarity, and country-level governance ("institutional responsibility"); and their effects are more persistent than the impact of shareholder-orientation (ADRI) and economic development; (2) The effects of political institutions are not significant, neither over long nor short time spans. (3) Only since around 2005, democracy has a slightly positive impact on sustainability, which implies that well-developed institutions are not a pre-condition for sustainability but co-evolves with it. Thus, our country-level results are largely consistent with the firm-level results.

\section{[Insert Table 10 about Here]}

\section{Shareholder Value Implication of CSR}

Finally, we consider the implications of CSR on shareholder value, which has not yet been explored within a cross-country setting in the extant "doing well by doing good" literature. As the typical endogeneity issue between doing well (shareholder value) and doing good (CSR) emerges, we apply a 2SLS approach to address this issue by using country-level variables as instruments for CSR. CSR is a very broad concept such that there is understandably no readily available single instrumental variable that captures all aspects. Furthermore, most of the macro indicators assembled by the World Bank, such as environmental factsheets, employment and labor participation data, etc., are arguably influenced by micro-level CSR as well. Given these constraints, we focus on one specific aspect of CSR, namely labor and social protections, and resort to the instrumental variables that proxy for truly exogenous legal rules rather than for the consequences of corporate labor relations. We use the labor regulation index developed by Botero, Djankov, La Porta, Lopez-de-Silanes, and Shleifer (2004), which has been used as a proxy for the stakeholder orientation of a country's legal system (Dhaliwal, Radhakrishnan, Tsang, and Yang, 2012), and encompasses four bodies of law_employment law, collective relations law, social 
security law, and civil rights law — and is believed to stem from a country's legal origin, and not influence shareholder value through channels other than labor and social protection (Dhaliwal et al., 2012).

The results of 2SLS regressions are shown in Table 11. The dependent variable in the second stage is the winsorized (at 5\%) Tobin's Q, defined as the ratio of the market capitalization of equity to the book value of total assets. The CSR indices_-predicted by labor regulations in the first stage-are those related to labor and social protection and comprise the RiskMetrics Social Rating, Labor Relations, Human Capital, and Stakeholder Capital from the MSCI IVA sample, as well as Human Resources and Human Rights from the Vigeo ESG sample. We document that the coefficients of various labor and social protection measures are consistently positive and significant, indicating that CSR, at least the part related to labor and social issues, does contribute to the creation of shareholder wealth. It also implies that finance and social responsibility are not necessarily in conflict as in the Friedman's (1970) view. In fact, maximizing stakeholder value can be consistent with maximizing the value of shareholders who belong to the broader group of stakeholders.

[Insert Table 11 about Here]

\section{Discussion and Conclusion}

In the economic literature, the nature of the truly fundamental, and largely exogenous, determinants of various economic outcomes is still unresolved. La Porta et al. (2008: 326) claim that “.... legal origins — broadly interpreted as highly persistent systems of social control of economic life—have significant consequences for the legal and regulatory framework of the society, as well as for economic outcomes.” In this paper, we focus on an important economic outcome, namely corporate social responsibility and societal sustainability that constitute a good society in the words of Shiller (2012). We have set out to examine, from the perspective of promoting sustainable development, the foundations of CSR and its implication for firm value. We assess CSR using proxies for corporate stakeholder 
concerns, such as their environmental, social, and governance policies which measure both engagement and compliance. In particular, by means of large-scale public and proprietary databases of CSR engagement and compliance to ESG issues, we find that legal origins are the main predictors of CSR, whereas political institutions such as democratic participation and constraints on government, culture, firm-level corporate governance, and financial performance are not. Country-level regressions confirm our firm-level results: legal origins are the most fundamental sources of sustainability, while political institutions are only correlated with the economic outcome of sustainable development in a recent time window, but are not a pre-condition.

Our results yield a strikingly different picture of legal origins than that described by LLSV and numerous other law and finance studies which draw implications on social welfare. Whereas LLSV show that the English common law origin is superior in terms of judicial efficiency, protection against state expropriation, accounting standards, financial development, and more active IPO and acquisition markets, we find that the English legal origin fosters CSR performance significantly less than countries under civil law origins. Our results are consistent with those of LLSV in that English legal origin comprises a shareholder-orientation whereas civil law is more stakeholder-oriented which stimulates CSR. We find that companies under the Scandinavian legal origin assume most CSR. Companies under the German legal origin outperform in terms of the adoption of environmental policies, while companies under the French legal origin outperform in social and labor-related issues. Our results hold for both CSR engagement and CSR compliance. Moreover, civil law countries obtain higher country-level environmental, social, and governance sustainability ratings than common law countries.

None of our empirical results and arguments are to deny the importance of finance and shareholder value in a society. As pointed out by Shiller (2012), a well-functioning system of financial capitalism with strong corporate governance can indeed contribute to a good society, which is confirmed 
by our empirical results on the positive link between shareholder protection, CSR, and Tobin's Q. Our key argument here is that a pure financial capitalism that exclusively dedicated to shareholders without considering the externalities on other stakeholders may by suboptimal to the society. In addition, our findings are not to refuse the merits of democracy and the constraints on government as essential human values in their own right. Rather, as countries become more economically developed, they also gradually improve their institutions. In fact, institutional responsibility-democratic participation and constraints on government - does not seem to be a precondition for economic sustainability that hinges on the firms' collective adoption of CSR. Democracy, due to its difficulty in consensus building, can often impede the adoption of sustainability at the micro-level through discouraging socially-minded managers from engaging in CSR. Overall, our study provides some implications useful for policymakers aiming at stimulating socially responsible and sustainable development. 


\section{REFERENCES}

Acemoglu, D., Johnson, S., 2005. Unbundling institutions. Journal of Political Economy 113, 949-995.

Acemoglu, D., Johnson, S., Robinson, J. A., 2001. The colonial origins of comparative development: an empirical investigation. American Economic Review 91, 1369-1401.

Acemoglu, D., Naidu, S., Restrepo, P., Robinson, J. A. 2013. Democracy, redistribution and inequality. NBER Working Paper No. 19746.

Allen, F., Carletti, E., Marquez, R., 2008. Stakeholder capitalism, corporate governance, and firm value. Wharton Finance Working Paper No. 09-28,

Allen, F., Qian, J., Zhang, C., 2011. An alternative view on law, institutions, finance and growth. Wharton Finance Working Paper No. 11-64.

Alsakka, R., Gwilym, O., 2010. A random effects ordered probit model for rating migrations. Financial Research Letters 7, 140-147.

Anderson, R. C., Reeb, D. M. 2003. Founding family ownership and firm performance: evidence from the S\&P 500 Journal of Finance 58, 1301-1328.

Aslan, H., Kumar, P., 2012. Strategic ownership and the cost of debt. Review of Financial Studies 25, 2257-2299.

Barnea, A., Rubin, A. 2010. Corporate social responsibility as a conflict between shareholders. Journal of Business Ethics 97, 71-86.

Barth, J. R., Caprio, G. Jr., Levine, R., 2006. Rethinking Bank Regulation: Till Angels Govern.Cambridge University Press, New York.

Barro, R. J., 1996. Democracy and growth. Journal of Economic Growth 1, 1-27.

Beck, T., Demirguc-Kunt, A., Levine, R., 2003. Law, endowments, and finance. Journal of Financial Economic 70, 137-181.

Beck, T., Levine, R., Loayza, N., 2000. Finance and the sources of growth. Journal of Financial Economics 58, 261-300.

Benabou, R., Tirole, J. 2010. Individual and corporate social responsibility. Economica 77, 1-19.

Berle, A., Means, G., 1932. The Modern Corporation and Private Property. Macmillian, New York.

Botero, J. C., Djankov, S., La Porta, R., Lopez-de-Silanes, F., Shleifer, A. 2004. The regulation of labor. Quarterly Journal of Economics 119(4), 1339-1382.

Chen, H., Chen, S., 2012. Investment-cash flow sensitivity cannot be a good measure of financial constraints: evidence from the time series. Journal of Financial Economics 103, 393-410.

Cheng, I.-H., Hong, H. G., Shue, K. 2013. Do managers do good with other people's money? Chicago Booth Research Paper No. 12-47.

Cheng, B., Ioannou, I., Serafeim, G., 2012. Corporate social responsibility and access to finance. Strategic Management Journal, forthcoming.

Claessens, S., Djankov, S. Lang, L. H.P., 2000. The separation of ownership and control in East Asian corporations. Journal of Financial Economics 58, 81-112.

Deng, X., Kang, J.-K., Low, B. S., 2013. Corporate social responsibility and stakeholder value maximization: evidence from mergers. Journal of Financial Economics 110, 87-109.

Dhaliwal, D. S., Radhakrishnan, S., Tsang, A., Yang, Y. G., 2012. Nonfinancial disclosure and analyst forecast accuracy: International evidence on corporate social responsibility disclosure. The Accounting Review 87(3): 723-759.

Dimson, E., Karakas, O., Li, X, 2013. Active ownership. London Business School Working Paper London Business School.

Djankov, S., La Porta, R., Lopez-de-Silanes, F., Shleifer, A. 2002. The regulation of entry. Quarterly Journal of Economics 117, 1-37.

Djankov, S., La Porta, R., Lopez-de-Silanes, F., Shleifer, A. 2008. The law and economics of self-dealing. Journal of Financial Economics 88, 430-465.

Doidge, C., Karolyi, A., Stulz, R. 2007. Why do countries matter so much for corporate governance? Journal of Financial Economics 86, 1-39.

Donaldson, T., Preston, L. E., 1995. The stakeholder theory of the corporation: concepts, evidence, and implications. Academy of Management Review 20, 65-91.

Dowell, G., Hart, S., Yeung, B., 2000. Do corporate global environmental standards create or destroy market value? Management Science 46, 1059-1074.

Edmans, A., 2011. Does the stock market fully value intangibles? Employee satisfaction and equity prices. Journal of Financial Economics 101, 621-640.

Edmans, A., 2011. The link between job satisfaction and firm value, with implications for corporate social responsibility. Academy of Management Perspectives 26, 1-19.

Easterly, W., Levine, R., 2003. Tropics, germs, and crops: how endowments influence economic development. 
Journal of Monetary Economics 50, 3-39.

Fazzari, S. M., Hubbard, R. G., Petersen, B. C. 1988. Financing constraints and corporate investment. Brookings Papers on Economic Activity 1, 141-206.

Freeman, R. E., 1984. Strategic Management: A Stakeholder Approach. Pitman, Boston, MA.

Friedman, M., 1970. The social responsibility of business is to increase its profits, New York Times Magazine, 122-126.

Fogel, K., Morck, R., Yeung, B., 2008. Big business stability and economic growth: is what's good for general motors good for America? Journal of Financial Economics 89, 83-108.

Gelter, M., 2009. The dark side of shareholder influence: managerial autonomy and stakeholder orientation in comparative corporate governance. Harvard International Law Journal 50, 129-194.

Glaeser, E. L., La Porta, R., Lopez-de-Silanes, F. Shleifer, A., 2004. Do institutions cause growth? Journal of Economic Growth 9, 271-303.

Guenster, N., Bauer, R., Derwall, J. Koedijk, K. 2011. The economic value of corporate eco-efficiency. European Financial Management 17, 679-704.

Guiso, L., Sapienza, P., Zingales, L., 2006. Does culture affect economic outcomes? Journal of Economic Perspectives 20, 23-48.

Henderson, R., Ramanna, K. 2013. Managers and market capitalism. Harvard Business School Working Paper No 13-075.

Hofstede, G., Hofstede, G. J. 2005. Cultures and Organizations: Software of the Mind (2nd edition). McGraw-Hill, New York.

Hong, H. G., Kubik, J. D., Scheinkman, J. A., 2012. Financial constraints and corporate goodness. NBER Working Paper No. 18476 .

Ioannou, I., Serafeim, G., 2012. What drives corporate social performance? The role of nation-level institutions, Journal of International Business Studies 43, 834-864.

Jensen, M. C., 2001. Value maximization, stakeholder theory and the corporate objective function. Journal of Applied Corporate Finance, 8-21.

King, R. G., Levine, R. 1993. Finance and growth: Schumpeter might be right. Quarterly Journal of Economics 108, 717-737.

Kitzmueller, M., Shimshack, J. 2012. Economic perspectives on corporate social responsibility. Journal of Economic Literature 50(1), 51-84.

Konar, S., Cohen, M. A., 2001. Does the market value environmental performance? Review of Economics and Statistics 83, 281-289.

Krueger, P., 2013. Corporate goodness and shareholder wealth. Geneva Finance Research Institute Working Paper.

La Porta, R., Lopez-de-Silanes, F., Shleifer, A., Vishny, R. W., 1997. Legal determinants of external finance. Journal of Finance 52, 1131-1150.

La Porta, R., Lopez-de-Silanes, F., Shleifer, A., Vishny, R. W. 1998. Law and finance. Journal of Political Economy 106(6), 1134-1155.

La Porta, R., Lopez-de-Silanes, F., Shleifer, A., Vishny, R. W., 1999. The quality of government. Journal of Law, Economics, and Organization 15, 222-279.

La Porta, R., Lopez-de-Silanes, F., Shleifer, A., 2008. The economic consequence of legal origins. Journal of Economic Literature 46, 285-332.

Levine, R., 1997. Financial development and economic growth: views and agenda. Journal of Economic Literature 35 , 688-726.

Luo, X., Bhattacharya, C.B., 2006. Corporate social responsibility, customer satisfaction, and market value. Journal of Marketing 70, 1-18.

Margolis, J. D., Elfenbein, H. A., Walsh, J. P. 2007. Does it pay to be good? A meta-analysis and redirection of the relationship between corporate social and financial performance. Harvard Business School Working Paper.

Martynova, M., Renneboog, L., 2011. Evidence on the international evolution and convergence of corporate governance regulations. Journal of Corporate Finance 17, 1531-1557.

Matten, D., Moon, J. 2008. 'Implicit' and 'explicit' CSR: a conceptual framework for a comparative understanding of corporate social responsibility. Academy of Management Review 33, 404-424.

Moon, J., Vogel, D., 2008. Corporate social responsibility, government, and civil society. In: Crane, A., McWilliams, A., Matten, D., Moon, J., Siegel, D., (Eds.), Oxford Handbook of Corporate Social Responsibility, Oxford University Press.

Morck, R., Wolfenzon, D., Yeung, B., 2005. Corporate governance, economic entrenchment, and growth. Journal of Economic Literature 43(3), 655-720.

North, D. C., 1981. Structure and Change in Economic History.Norton, New York.

North, D. C., Weingast, B. R., 1989. Constitutions and commitment: the evolution of institutions governing 
public choice in seventeenth-century England. Journal of Economic History 44, 803-832.

Orlitzky, M., Schmidt, F. L. Rynes, S. L., 2003. Corporate social and financial performance: a meta-analysis. Organization Studies 24, 403-441.

Pagano, M., Volpin, P. F. 2005. The political economy of corporate governance. American Economic Review 95, 1005-1030.

Perotti, E. C., von Thadden, E.-L., 2006. The political economy of corporate control and labor rents. Journal of Political Economy 114, 145-174.

Perotti, E. C., Schwienbacher, A., 2009. The political origin of pension funding. Journal of Financial Intermediation 18, 384-404.

Porter, M. E., 1991. American's green strategy. Scientific American 264, 168.

Porter, M. E., van der Linder, C., 1995. Toward a new conception of the environment-competitiveness relationship. Journal of Economic Perspective 9, 97-118.

Rajan, R. G., Zingales, L., 1998. Financial development and growth. American Economic Review 88, $559-586$.

Rajan, R.,G., Zingales, L., 2003. The great reversals: the politics of financial development in the rwentieth century. Journal of Financial Economics 69, 5-50.

Renneboog, L., ter Horst, J., Zhang, C. 2008. The price of ethics and stakeholder governance: the performance of socially responsible mutual funds. Journal of Corporate Finance 14, 302-322.

Renneboog, L., ter Horst, J., Zhang, C., 2011. Is ethical money financially smart? Nonfinancial attributes and money flows of socially responsible investment funds. Journal of Financial Intermediation 20, 562-588.

Rodrik, D., 1999. Democracies pay higher wages. Quarterly Journal of Economics 114, 707-738.

Rodrik, D., Subramanian, A., Trebbi, F., 2004. Institutions rule: the premacy of institutions over geography and integration in economic development. Journal of Economic Growth 9, 131-165.

Roe, M. J., 2003. Political Determinants of Corporate Governance. Oxford University Press, Oxford.

Roe, M. J., 2006. Legal origins, politics, and modern stock markets. Harvard Law Review 120, 462-527.

Seifert, B., Morris, S. A., Bartkus, B. R., 2004. Having, giving, and getting: slack resources, corporate philanthropy, and firm financial performance, Business and Society 43, 135-161.

Servaes, H., Tamayo, A. 2013. The impact of corporate social responsibility on firm value: the role of customer awareness. Management Science, forthcoming.

Shiller, R. J. 2012. Finance and the Good Society. Princeton University Press, New Jersey.

Spamann, H., 2010. “'The 'antidirector rights index' revisited. Review of Financial Studies 23, 467-486.

Stulz, R. M., Williamson, R. 2003. Culture, openness, and finance. Journal of Financial Economics 70, 313-349.

Tabellini, G., 2010. Culture and institutions: economic development in the regions of Europe. Journal of European Economic Association 8, 677-716.

Tirole, J., 2001. Corporate governance. Econometrica 69, 1-35.

Williamson, O. E., 1981. The modern corporation: origins, evolution, attributes. Journal of Economic Literature 19, 1537-1568.

Williamson, O. E., 1985. The Economic Institutions of Capitalism. The Free Press, New York. 


\section{Table 1. Intangible Value Assessment (IVA) Data Description}

\begin{tabular}{|c|c|c|c|}
\hline IVA Factor & IVA Subscore & weight & Key Metrics \\
\hline \multirow{3}{*}{$\begin{array}{l}\text { Strategic } \\
\text { governance }\end{array}$} & SG1) Strategy & $<2 \%$ & Overall governance; rating composed of total scores of non-Key Issues \\
\hline & $\begin{array}{l}\text { SG2) Strategic Capability } \\
\text { / Adaptability }\end{array}$ & $<2 \%$ & Management of CSR issues, partnership in multi-stakeholder initiatives \\
\hline & $\begin{array}{l}\text { SG3) Traditional } \\
\text { Governance Concerns }\end{array}$ & $<2 \%$ & $\begin{array}{l}\text { Board independence, management of CSR issues, board diversity, compensation } \\
\text { practices, controversies involving executive compensation and governance. }\end{array}$ \\
\hline \multirow[t]{4}{*}{ Human capital } & $\begin{array}{l}\text { HC1) Workplace } \\
\text { Practices }\end{array}$ & $<2 \%$ & $\begin{array}{l}\text { Workforce diversity, policies and programs to promote diversity, work/life } \\
\text { benefits, discrimination-related controversies }\end{array}$ \\
\hline & HC2) Labor Relations & $20 \%$ & KEY ISSUE: Labor Relations \\
\hline & & & Benefits, strikes, union relations, controversies, risk of work stoppages, etc. \\
\hline & HC3) Health \& Safety & $<2 \%$ & $\begin{array}{l}\text { H\&S policies and systems, implementation and monitoring of those systems, } \\
\text { performance (injury rate, etc.), safety-related incidents and controversies }\end{array}$ \\
\hline \multirow[t]{3}{*}{$\begin{array}{l}\text { Stakeholder } \\
\text { capital }\end{array}$} & $\begin{array}{l}\text { SC1) Stakeholder } \\
\text { Partnerships }\end{array}$ & $<2 \%$ & $\begin{array}{l}\text { Customer initiatives, customer-related controversies, firm's support for public } \\
\text { policies with noteworthy benefits for stakeholders }\end{array}$ \\
\hline & SC2) Local Communities & $<2 \%$ & $\begin{array}{l}\text { Policies, systems and initiatives involving local communities (esp. indigenous } \\
\text { peoples), controversies related to firm's interactions with communities }\end{array}$ \\
\hline & SC3) Supply Chain & $<2 \%$ & $\begin{array}{l}\text { Policies and systems to protect supply-chain workers' and contractors' rights, } \\
\text { initiatives toward improving labor conditions, supply-chain-related controversies }\end{array}$ \\
\hline \multirow[t]{2}{*}{$\begin{array}{l}\text { Products and } \\
\text { services }\end{array}$} & $\begin{array}{l}\text { PS1) Intellectual Capital/ } \\
\text { Product Development }\end{array}$ & $<2 \%$ & $\begin{array}{l}\text { Beneficial products and services, including efforts that benefit the disadvantaged, } \\
\text { reduce consumption of energy and resources, and production of hazardous } \\
\text { chemicals; average of two scores }\end{array}$ \\
\hline & PS2) Product Safety & $<2 \%$ & $\begin{array}{l}\text { Product quality, health and safety initiatives, controversies related to the quality or } \\
\text { safety of a firm's products, including legal cases, recalls, criticism }\end{array}$ \\
\hline \multirow{3}{*}{$\begin{array}{l}\text { Emerging } \\
\text { markets }\end{array}$} & EM1) EM Strategy & $<2 \%$ & Default $=5$, unless there is company specific exposure that is highly significant \\
\hline & $\begin{array}{l}\text { EM2) Human Rights/ } \\
\text { Child and Forced Labor }\end{array}$ & $<2 \%$ & $\begin{array}{l}\text { Policies, support for values in Universal Declaration of Human Rights, initiatives } \\
\text { to promote human rights, human rights controversies }\end{array}$ \\
\hline & EM3) Oppressive regimes & $<2 \%$ & Controversies, substantive involvement in countries with poor HR records \\
\hline \multirow[t]{7}{*}{$\begin{array}{l}\text { Environmental } \\
\text { risk factors }\end{array}$} & ER1) Historic Liabilities & $<2 \%$ & $\begin{array}{l}\text { Controversies including natural resource-related cases, widespread or egregious } \\
\text { environmental impacts }\end{array}$ \\
\hline & ER2) Operating Risk & $<2 \%$ & $\begin{array}{l}\text { Emissions to air, discharges to water, emission of toxic chemicals, nuclear energy, } \\
\text { controversies involving non-GHG emissions }\end{array}$ \\
\hline & ER3) Leading/ & $<2 \%$ & Water management and use, use of recycled materials, sourcing, sustainable \\
\hline & Sustainability Risk & & resource management, climate change policy and transparency, climate change \\
\hline & Indicators & & initiatives, absolute and normalized emissions output, controversies \\
\hline & ER4) Industry Carbon & $25 \%$ & KEY ISSUE: Carbon \\
\hline & Specific Risk & & Targets, emissions intensity relative to peers, estimated cost of compliance \\
\hline \multirow{8}{*}{$\begin{array}{l}\text { Environmental } \\
\text { management } \\
\text { capacity }\end{array}$} & $\begin{array}{l}\text { EMC1) Environmental } \\
\text { Strategy }\end{array}$ & $<2 \%$ & $\begin{array}{l}\text { Policies to integrate environmental considerations into all operations, } \\
\text { environmental management systems, regulatory compliance, controversies }\end{array}$ \\
\hline & $\begin{array}{l}\text { EMC2) Corporate } \\
\text { Governance }\end{array}$ & $<2 \%$ & $\begin{array}{l}\text { Board independence, management of CSR issues, board diversity, compensation } \\
\text { practices, controversies involving executive compensation and governance. }\end{array}$ \\
\hline & $\begin{array}{l}\text { EMC3) Environmental } \\
\text { Management Systems }\end{array}$ & $<2 \%$ & $\begin{array}{l}\text { Establishment and monitoring of environmental performance targets, presence } \\
\text { of environmental training, stakeholder engagement }\end{array}$ \\
\hline & EMC4) Audit & $<2 \%$ & External independent audits of environmental performance \\
\hline & $\begin{array}{l}\text { EMC5) Environmental } \\
\text { Accounting/Reporting }\end{array}$ & $<2 \%$ & Reporting frequency, reporting quality \\
\hline & $\begin{array}{l}\text { EMC6) Environmental } \\
\text { Training \& Development }\end{array}$ & $<2 \%$ & Presence of environmental training and communications programs for employees \\
\hline & EMC7) Certification & $<2 \%$ & Certifications by ISO or other industry- and country-specific third party auditors \\
\hline & $\begin{array}{l}\text { EMC8) Products/ } \\
\text { Materials }\end{array}$ & $<2 \%$ & $\begin{array}{l}\text { Positive and negative impact of products \& services, end-of-life product } \\
\text { management, controversies related to environmental impact of P\&S. }\end{array}$ \\
\hline \multirow[t]{4}{*}{$\begin{array}{l}\text { Environmental } \\
\text { opportunity } \\
\text { factors }\end{array}$} & $\begin{array}{l}\text { EO1) Strategic } \\
\text { Competence }\end{array}$ & $<2 \%$ & $\begin{array}{l}\text { Policies to integrate environmental considerations into all operations and reduce } \\
\text { environmental impact of operations, products \& services, environmental } \\
\text { management systems, regulatory compliance }\end{array}$ \\
\hline & EO2) Environmental & $35 \%$ & KEY ISSUE: Opportunities in clean technology \\
\hline & Opportunity & & $\begin{array}{l}\text { Product development in clean technology, } \mathrm{R} \& \mathrm{D} \text { relative to sales and trend, } \\
\text { innovation capacity }\end{array}$ \\
\hline & EO3) Performance & $<2 \%$ & Percent of revenue represented by identified beneficial products \& services \\
\hline
\end{tabular}


Table 2. Average CSR Score across Different Legal Origins.

The Overall IVA Rating is the weighted average score for different subcategories onwards. EcoValue 21 Rating and Social Rating are from RiskMetrics. A higher score signifies that the company put more effort in the issue, and is marked by a darker color. Standard deviations are in brackets.

\section{General Ratings}

Overall IVA Rating

EcoValue 21 Rating

Social Rating

\section{Strategic Governance}

Strategic Governance Strategy

Strategic Capability Adaptability

Traditional Governance Concerns

\section{Human Capital}

Employee Motivation Development

Labor Relations

Health Safety

\section{Stakeholder Capital}

Customer Stakeholder Partnerships

Local Communities

Supply Chain

\section{Products and Services}

Intellectual Capital Product Develop.

Product Safety

\section{Emerging Market}

Emerging Market Strategy

Human Rights Child and Forced Labor

Oppressive Regimes

\section{Environment (Overall)}

\section{Environmental Risk Factors}

Historic Liabilities

Operating Risk

Leading Sustainability Risk Indicator

Industry Specific Carbon Risk

\section{Environmental Mgmt. Capacity}

Environmental Strategy

Corporate Governance

Environmental Management Systems

Audit

Environmental Accounting/ Reporting

Environmental Training Development

Certification

Products Materials

\section{Environmental Opportunity Factors}

Strategic Competence

Environmental Opportunity

Performance
English origin French origin Socialist origin German origin Scandinavian origin

\begin{tabular}{llllll}
$2.72(1.74)$ & $3.10(1.73)$ & $1.26(1.21)$ & $2.83(1.72)$ & $3.93(1.74)$ \\
$2.65(1.77)$ & $2.92(1.78)$ & $1.20(1.21)$ & $3.59(1.85)$ & $3.88(1.70)$ \\
$2.75(1.73)$ & $2.99(1.75)$ & $1.40(1.36)$ & $2.84(1.63)$ & $3.85(1.66)$ \\
\hline $5.42(1.85)$ & $5.58(1.85)$ & $3.89(1.57)$ & $5.49(1.82)$ & $6.66(1.73)$ \\
$5.47(2.23)$ & $5.91(2.23)$ & $4.01(2.09)$ & $6.01(2.05)$ & $6.76(2.02)$ \\
$5.28(2.30)$ & $5.63(2.15)$ & $3.83(2.17)$ & $5.76(2.16)$ & $6.38(2.17)$ \\
$5.57(1.97)$ & $5.31(2.00)$ & $4.56(2.21)$ & $4.93(2.07)$ & $6.60(1.84)$ \\
\hline $5.56(1.69)$ & $5.88(1.74)$ & $4.06(1.67)$ & $5.44(1.73)$ & $6.39(1.72)$ \\
$5.93(2.00)$ & $6.30(2.01)$ & $4.85(2.12)$ & $5.71(1.92)$ & $6.61(2.10)$ \\
$5.26(1.85)$ & $5.62(2.03)$ & $4.25(2.25)$ & $5.51(1.76)$ & $6.13(2.01)$ \\
$5.45(2.14)$ & $5.51(2.01)$ & $3.75(1.97)$ & $5.27(2.09)$ & $6.07(2.11)$ \\
$5.33(1.87)$ & $5.44(1.86)$ & $3.97(1.25)$ & $5.23(1.78)$ & $5.78(1.91)$ \\
$5.21(2.14)$ & $5.46(2.14)$ & $4.01(2.03)$ & $5.42(2.00)$ & $6.09(2.10)$ \\
$5.86(2.21)$ & $5.63(2.10)$ & $4.84(1.88)$ & $5.51(2.01)$ & $5.28(1.96)$ \\
$5.12(2.31)$ & $5.09(2.20)$ & $3.65(2.32)$ & $5.21(2.15)$ & $5.75(2.38)$
\end{tabular}

\begin{tabular}{l|l|l|l}
$5.42(2.34)$ & $5.78(2.25)$ & $3.98(1.96)$ & $6.18(2.29)$ \\
$5.17(2.02)$ & $5.37(2.25)$ & $3.84(2.34)$ & $5.39(2.11)$ \\
\hline
\end{tabular}

$6.34(1.95)$

$5.88(2.07)$

5.1

\begin{tabular}{lllll}
$5.37(1.90)$ & $5.61(1.87)$ & $4.54(1.85)$ & $5.27(1.80)$ & $5.85(1.97)$ \\
$5.10(2.12)$ & $5.16(2.05)$ & $4.60(2.08)$ & $5.11(1.94)$ & $5.98(2.13)$ \\
$5.11(2.13)$ & $5.00(1.98)$ & $4.78(2.08)$ & $4.97(1.97)$ & $5.34(2.05)$ \\
\hline $4.66(1.64)$ & $4.87(1.76)$ & $3.06(1.29)$ & $5.49(1.70)$ & $5.70(1.56)$ \\
$5.13(1.92)$ & $5.09(1.75)$ & $3.57(1.38)$ & $5.47(1.57)$ & $6.03(1.40)$ \\
$5.22(2.59)$ & $4.92(2.35)$ & $3.21(1.64)$ & $5.25(2.14)$ & $6.02(2.03)$ \\
$4.96(2.40)$ & $4.52(2.46)$ & $3.01(2.08)$ & $5.14(2.22)$ & $5.59(2.48)$ \\
$4.80(2.02)$ & $5.01(1.99)$ & $3.41(1.65)$ & $5.63(1.94)$ & $5.83(1.90)$ \\
$4.35(2.59)$ & $4.39(2.75)$ & $3.66(2.35)$ & $4.84(2.54)$ & $5.33(2.38)$ \\
$4.07(2.19)$ & $4.55(2.13)$ & $3.21(1.76)$ & $5.46(2.13)$ & $5.59(2.17)$ \\
$4.93(2.41)$ & $5.34(2.38)$ & $4.06(2.13)$ & $6.15(2.28)$ & $6.54(2.24)$ \\
$4.00(2.45)$ & $4.06(2.30)$ & $3.38(2.18)$ & $5.09(2.31)$ & $4.90(2.31)$ \\
$3.93(2.57)$ & $4.68(2.66)$ & $2.98(2.20)$ & $5.83(2.64)$ & $5.77(2.62)$ \\
$4.03(2.77)$ & $4.26(2.79)$ & $3.36(2.66)$ & $5.35(2.84)$ & $5.20(2.94)$ \\
$3.54(2.54)$ & $4.26(2.47)$ & $2.72(2.18)$ & $5.57(2.90)$ & $5.39(2.71)$ \\
$4.18(2.77)$ & $4.71(2.64)$ & $3.52(2.62)$ & $5.67(2.60)$ & $5.69(2.84)$ \\
$2.75(2.54)$ & $3.07(2.52)$ & $2.13(2.11)$ & $3.46(2.55)$ & $3.57(2.85)$ \\
$3.51(2.53)$ & $4.11(2.43)$ & $2.28(1.81)$ & $4.94(2.68)$ & $5.36(2.61)$ \\
\hline $5.14(1.89)$ & $5.17(2.09)$ & $4.17(1.62)$ & $5.59(1.90)$ & $6.09(1.83)$ \\
$4.38(2.54)$ & $4.92(2.48)$ & $3.52(1.93)$ & $6.06(2.43)$ & $5.98(2.51)$ \\
$4.47(2.25)$ & $4.93(2.21)$ & $3.49(1.83)$ & $5.75(2.21)$ & $5.87(2.08)$ \\
$4.20(2.71)$ & $4.63(2.64)$ & $3.30(2.15)$ & $5.57(2.68)$ & $5.65(2.45)$ \\
\hline
\end{tabular}


Table 3. Non-parametric Tests on the Means of CSR indices by Legal Origins. (Wilcoxon-Mann-Whitney Test Statistics)

The Wilcoxon-Mann-Whitney signed-rank test compares two subsamples of different legal origins to assess whether their population firm-time mean ranks differ. *, $* *, * *$ stand for statistical significance at the $10 \%, 5 \%$, and $1 \%$, respectively. Standard errors (not reported) are clustered at the country level.

\begin{tabular}{lllllll}
\hline & $\begin{array}{l}\text { Overall IVA } \\
\text { Rating }\end{array}$ & $\begin{array}{l}\text { EcoValue } 21 \\
\text { Rating }\end{array}$ & $\begin{array}{l}\text { Social } \\
\text { Rating }\end{array}$ & $\begin{array}{l}\text { Labor } \\
\text { Relations }\end{array}$ & $\begin{array}{l}\text { Industry Specific } \\
\text { Carbon Risk }\end{array}$ & $\begin{array}{l}\text { Environmental } \\
\text { Opportunity }\end{array}$ \\
\hline $\begin{array}{l}\text { Civil vs. common } \\
\text { legal origin }\end{array}$ & $18.676^{* * *}$ & $58.391^{* * *}$ & $19.059^{* * *}$ & $23.905^{* * *}$ & $22.369^{* * *}$ & $34.366^{* * *}$ \\
\hline $\begin{array}{l}\text { French vs. English } \\
\text { origin }\end{array}$ & $16.044^{* * *}$ & $15.241^{* * *}$ & $12.046^{* * *}$ & $16.333^{* * *}$ & $1.855^{*}$ & $4.907^{* * *}$ \\
$\begin{array}{l}\text { German vs. } \\
\text { English origin }\end{array}$ & $3.994^{* * *}$ & $58.977^{* * *}$ & $5.906^{* * *}$ & $13.480^{* * *}$ & $22.050^{* * *}$ & $33.680^{* * *}$ \\
$\begin{array}{l}\text { Scandinavian vs. } \\
\text { English origin }\end{array}$ & $29.299^{* * *}$ & $40.474^{* * *}$ & $32.592^{* * *}$ & $24.327^{* * *}$ & $24.112^{* * *}$ & $33.527^{* * *}$ \\
$\begin{array}{l}\text { French vs. German } \\
\text { origin }\end{array}$ & $11.026^{* * *}$ & $-30.546^{* * *}$ & $6.623^{* * *}$ & $5.194^{* * *}$ & $-13.318^{* * *}$ & $-18.235^{* * *}$ \\
$\begin{array}{l}\text { French vs. } \\
\text { Scandinavian } \\
\text { origin }\end{array}$ & $-18.879^{* * *}$ & $-28.764^{* * *}$ & $-23.121^{* * *}$ & $-12.277^{* * * *}$ & $-19.137^{* * *}$ & $-25.728^{* * *}$ \\
$\begin{array}{l}\text { German vs. } \\
\text { Scandinavian } \\
\text { origin }\end{array}$ & $-26.137^{* * *}$ & $-8.600^{* * *}$ & $-29.329^{* * *}$ & $-17.580^{* * * *}$ & $-11.923^{* * *}$ & $-16.326^{* * *}$ \\
\hline $\begin{array}{l}\text { Capitalist vs. } \\
\text { Socialist origin }\end{array}$ & $16.994^{* * *}$ & $27.184^{* * *}$ & $22.259^{* * *}$ & $12.920^{* * *}$ & $10.496^{* * *}$ & $19.474^{* * *}$ \\
\hline & & & & & & \\
\hline
\end{tabular}




\section{Table 4. The Impact of}

\section{Legal Origins and Political Institutions on Corporate Social Responsibility (Random-Effect GLS and Pooled OLS Models).}

The dependent variable is the ordinal IVA rating (from 0 to 6 ). The independent variables are legal origins (omitting the English legal origin as the base case), political institutions (democracy index, corruption control, and political executive constraints), economic development (the logarithm of GDP per capita, and the KOF index of globalization), ownership and governance (ownership dispersion, tier structure or a supervisory board dummy, the ultimate owner [UO] dummies) and control variables (ROA, financial constraints, interest coverage, financial slack). The democracy index used in Column (1) - (3) are from the Polity IV index, while in Column (4) - (6) are from the Vanhanen democracy index. *, **, *** stand for statistical significance at the $10 \%, 5 \%$, and $1 \%$, respectively. Standard errors are clustered at the country level - except for Column (3) in which standard errors are clustered at the firm level - and are reported in parentheses.

\begin{tabular}{|c|c|c|c|c|c|c|c|c|c|c|c|c|}
\hline \multirow{2}{*}{$\begin{array}{l}\text { Dep. Var = IVA rating } \\
\text { Law }\end{array}$} & \multicolumn{2}{|c|}{$\begin{array}{l}\text { (1)Random Ef. } \\
\text { GLS }\end{array}$} & \multicolumn{2}{|c|}{$\begin{array}{l}\text { (2) Random Ef. } \\
\text { GLS }\end{array}$} & \multicolumn{2}{|c|}{$\begin{array}{l}\text { (3) Random Ef. } \\
\text { GLS }\end{array}$} & \multicolumn{2}{|c|}{$\begin{array}{l}\text { (4) Random Ef. } \\
\text { GLS }\end{array}$} & \multicolumn{2}{|c|}{$\begin{array}{l}\text { (5) Random Ef. } \\
\text { GLS }\end{array}$} & \multicolumn{2}{|c|}{$\begin{array}{l}\text { (6) Pooled } \\
\text { OLS }\end{array}$} \\
\hline & & & & & & & & & & & & \\
\hline French origin & $0.753^{* *}$ & $(0.347)$ & $0.616^{*}$ & $(0.346)$ & $0.813^{* * *}$ & $(0.146)$ & $1.364 * *$ & $(0.547)$ & $0.758^{*}$ & $(0.440)$ & $1.346^{* *}$ & $(0.571)$ \\
\hline German origin & $0.576^{* *}$ & $(0.277)$ & $0.797 * * *$ & $(0.283)$ & $0.758^{* * *}$ & $(0.149)$ & $1.649 * * *$ & $(0.339)$ & $0.823 * *$ & $(0.403)$ & 0.765 & $(0.514)$ \\
\hline Scandinavian origin & $0.677^{* *}$ & $(0.292)$ & $0.935^{* * *}$ & $(0.235)$ & $0.784 * * *$ & $(0.208)$ & $1.440 * * *$ & $(0.457)$ & $1.503^{* * *}$ & $(0.536)$ & $2.489 * * *$ & $(0.695)$ \\
\hline \multicolumn{13}{|l|}{ Political institutions } \\
\hline Democracy index & -0.053 & $(0.045)$ & 0.015 & $(0.097)$ & & & -0.004 & $(0.020)$ & $-0.057 * *$ & $(0.024)$ & $-0.071 *$ & $(0.040)$ \\
\hline Corruption control & & & -0.278 & $(0.190)$ & & & $0.913^{* *}$ & $(0.400)$ & & & & \\
\hline Executive constraints & & & & & 0.182 & $(0.146)$ & 0.095 & $(0.260)$ & $0.456^{* *}$ & $(0.174)$ & 0.269 & $(0.238)$ \\
\hline \multicolumn{13}{|l|}{ Economic development } \\
\hline Ln(GDP per capita) & $0.809^{* * *}$ & $(0.217)$ & $0.490^{* *}$ & $(0.239)$ & $0.395^{* * *}$ & $(0.142)$ & $-0.655^{* *}$ & $(0.268)$ & -0.035 & $(0.283)$ & -0.066 & $(0.365)$ \\
\hline Globalization index & $0.034 * *$ & $(0.015)$ & $0.048^{* * *}$ & $(0.015)$ & $0.041 * * *$ & $(0.009)$ & 0.047 & $(0.029)$ & $0.072^{* * *}$ & $(0.023)$ & 0.040 & $(0.025)$ \\
\hline \multicolumn{13}{|l|}{ Ownership and governance } \\
\hline Ownership dispersion & & & $0.043^{*}$ & $(0.024)$ & $0.038^{* *}$ & $(0.017)$ & -0.002 & $(0.161)$ & 0.087 & $(0.142)$ & 0.003 & $(0.125)$ \\
\hline Supervisory board & & & 0.371 & $(0.244)$ & $0.321 *$ & $(0.182)$ & $0.742 * *$ & $(0.298)$ & $1.109 * * *$ & $(0.273)$ & $0.972^{* * *}$ & $(0.343)$ \\
\hline $\mathrm{UO}$ - state & & & & & & & -0.479 & $(0.547)$ & -0.645 & $(0.443)$ & 0.069 & $(0.444)$ \\
\hline $\mathrm{UO}$ - families & & & & & & & -0.378 & $(0.626)$ & 0.185 & $(0.422)$ & 0.472 & $(0.357)$ \\
\hline $\mathrm{UO}$ - foundation & & & & & & & 0.043 & $(0.384)$ & $1.637^{*}$ & $(0.808)$ & 0.492 & $(0.675)$ \\
\hline $\mathrm{UO}$ - financial & & & & & & & 0.568 & $(0.513)$ & -0.269 & $(0.489)$ & -0.568 & $(0.559)$ \\
\hline UO - pension & & & & & & & $-1.312^{* * *}$ & $(0.467)$ & $-0.777 *$ & $(0.434)$ & -0.478 & $(0.525)$ \\
\hline $\mathrm{UO}-\mathrm{VC} / \mathrm{PE}$ & & & & & & & 1.139 & $(1.346)$ & 1.480 & $(0.991)$ & -0.913 & $(0.703)$ \\
\hline \multicolumn{13}{|l|}{ Controls } \\
\hline $\mathrm{ROA}$ & & & -0.317 & $(0.337)$ & -0.338 & $(0.424)$ & -2.542 & $(2.575)$ & -2.213 & $(2.472)$ & -0.870 & $(2.570)$ \\
\hline Interest coverage & & & 0.001 & $(0.001)$ & 0.001 & $(0.001)$ & 0.004 & $(0.004)$ & 0.006 & $(0.004)$ & $0.001 *$ & $(0.000)$ \\
\hline Financial constraints & & & $0.004 * *$ & $(0.002)$ & 0.004 & $(0.003)$ & 0.005 & $(0.115)$ & & & & \\
\hline Financial slack & & & -0.017 & $(0.015)$ & -0.018 & $(0.015)$ & $0.185^{* *}$ & $(0.079)$ & & & & \\
\hline Year FE & No & & Yes & & Yes & & Yes & & Yes & & No & \\
\hline Industry FE & No & & No & & No & & Yes & & Yes & & No & \\
\hline Constant & $-8.142^{* * *}$ & $(3.031)$ & $-6.217 * *$ & $(2.660)$ & $-6.178^{* * *}$ & $(1.402)$ & 2.390 & $(2.916)$ & -4.278 & $(2.690)$ & -0.631 & $(2.786)$ \\
\hline No. observations & 45789 & & 26124 & & 26124 & & 2436 & & 3185 & & 3185 & \\
\hline R-squared adj. & $3.6 \%$ & & $7.3 \%$ & & $7.4 \%$ & & $60.0 \%$ & & $51.9 \%$ & & $22.3 \%$ & \\
\hline
\end{tabular}


Table 5. Legal Origins, Political Institutions, and Corporate Social Responsibility (Random-Effects GLS).

The dependent variables are the ordinal (ranging from 0 to 6) EcoValue21 Rating, and Social Rating, as well as the ordinal (ranging from 0 to 10 ) Labor Relations, Industry Specific Carbon Risks, and Environmental Opportunity, respectively. The independent variables are legal origins (omitting the English legal origin as the base case), political institutions (democracy index, corruption control, and political executive constraints), ownership and governance (ownership dispersion, tier structure or a supervisory

board dummy, the ultimate owner [UO] dummies), and control variables (ROA, financial constraints, interest coverage, financial slack, and Ln(GDP per capita)). The

democracy index used in columns (1), (3), (5), (7), and (9) is from Polity IV, and that used in columns (2), (4), (6), (8), and (10) is from the Vanhanen index. *, **, *** stand

for statistical significance at the $10 \%, 5 \%$, and $1 \%$, respectively. Standard errors are clustered at the country level and reported in parentheses.

\begin{tabular}{|c|c|c|c|c|c|c|c|c|c|c|c|c|c|c|c|c|c|c|c|c|}
\hline \multirow[t]{2}{*}{ Dependent Variable } & \multicolumn{4}{|c|}{ EcoValue21 Rating } & \multicolumn{4}{|c|}{ Social Rating } & \multicolumn{4}{|c|}{ Labor Relations } & \multicolumn{4}{|c|}{ Industry-Specific Carbon Risks } & \multicolumn{4}{|c|}{ Environmental Opportunity } \\
\hline & \multirow{2}{*}{$(1)$} & \multicolumn{3}{|c|}{$(2)$} & \multirow{2}{*}{ (3) } & \multicolumn{3}{|c|}{$(4)$} & \multirow[t]{2}{*}{ (5) } & \multicolumn{3}{|c|}{$(6)$} & \multicolumn{2}{|c|}{$(7)$} & \multirow{2}{*}{\multicolumn{2}{|c|}{ (8) }} & \multirow[t]{2}{*}{ (9) } & \multicolumn{3}{|c|}{$(10)$} \\
\hline \multicolumn{15}{|l|}{ Law } & & & & & & \\
\hline French origin & $0.952 * *$ & $(0.395)$ & 0.369 & $(0.349)$ & 0.563 & $(0.360)$ & 0.601 & $(0.402)$ & $0.576^{* *}$ & $(0.291)$ & $0.726^{* * *}$ & $(0.250)$ & 0.155 & $(0.253)$ & -0.117 & $(0.397)$ & 0.243 & $(0.221)$ & 0.206 & $(0.212)$ \\
\hline German origin & $1.024 *$ & $(0.613)$ & $0.550^{* *}$ & $(0.247)$ & 0.101 & $(0.342)$ & $0.901 * *$ & $(0.371)$ & 0.317 & $(0.216)$ & 0.776 & $(0.569)$ & $0.675^{* * *}$ & $(0.253)$ & -0.377 & $(0.342)$ & $0.547 * * *$ & $(0.124)$ & $0.543^{* * *}$ & $=(0.072)$ \\
\hline Scandinavian origin & $0.948^{* * *}$ & $(0.324)$ & $1.203^{* *}$ & $(0.491)$ & $0.944 * * *$ & $=(0.300)$ & $1.476^{* * *}$ & $(0.494)$ & $0.655^{* * *}$ & $(0.224)$ & $0.837 *$ & $(0.430)$ & $1.046^{* * *}$ & $(0.296)$ & $0.611 *$ & $(0.344)$ & $0.800^{* * *}$ & $(0.170)$ & $0.627 * * *$ & $=(0.197)$ \\
\hline \multicolumn{21}{|c|}{$\mathrm{x}^{2}$} \\
\hline Democracy index & -0.047 & $(0.062)$ & -0.030 & $(0.022)$ & 0.013 & $(0.065)$ & $-0.042^{* *}$ & $(0.020)$ & -0.047 & $(0.039)$ & -0.001 & $(0.016)$ & -0.120 & $(0.117)$ & -0.005 & $(0.019)$ & -0.101 & $(0.067)$ & 0.013 & $(0.009)$ \\
\hline Executive constraints & & & $0.308^{*}$ & $(0.160)$ & & & 0.235 & $(0.176)$ & & & -0.158 & $(0.182)$ & & & 0.127 & $(0.188)$ & & & -0.090 & $(0.117)$ \\
\hline \multicolumn{21}{|l|}{ Economic development } \\
\hline Ln(GDP per capita) & $1.025^{*}$ & $(0.558)$ & $0.698^{* * *}$ & $(0.219)$ & $0.652^{* * *}$ & $=(0.210)$ & -0.045 & $(0.237)$ & $0.670^{* * *}$ & $(0.164)$ & 0.042 & $(0.356)$ & 0.026 & $(0.294)$ & $0.607 *$ & $(0.313)$ & $0.342^{*}$ & $(0.188)$ & $0.378^{* * *}$ & $=(0.129)$ \\
\hline Globalization index & 0.002 & $(0.031)$ & -0.017 & $(0.018)$ & -0.004 & $(0.009)$ & $0.056^{* * *}$ & $(0.018)$ & -0.004 & $(0.011)$ & $0.052^{* *}$ & $(0.024)$ & -0.003 & $(0.020)$ & $-0.050^{* *}$ & $(0.023)$ & 0.002 & $(0.006)$ & 0.001 & $(0.005)$ \\
\hline \multicolumn{21}{|l|}{ Ownership and governance } \\
\hline Ownership dispersion & 0.004 & $(0.018)$ & 0.089 & $(0.131)$ & 0.035 & $(0.021)$ & 0.138 & $(0.135)$ & 0.041 & $(0.031)$ & 0.137 & $(0.093)$ & 0.039 & $(0.040)$ & 0.001 & $(0.124)$ & $0.029 *$ & $(0.019)$ & $0.027 *$ & $(0.015)$ \\
\hline Supervisory board & 0.160 & $(0.465)$ & $0.847^{* *}$ & $(0.318)$ & $0.756^{* *}$ & $(0.317)$ & $0.618^{* *}$ & $(0.301)$ & $0.609 * * *$ & $(0.190)$ & $0.660^{* *}$ & $(0.260)$ & -0.127 & $(0.455)$ & $0.929 * * *$ & $=(0.245)$ & -0.007 & $(0.175)$ & 0.044 & $(0.106)$ \\
\hline $\mathrm{UO}$ - state & & & -0.029 & $(0.497)$ & & & $-0.795^{* *}$ & $(0.375)$ & & & $-1.144 * * *$ & $(0.346)$ & & & -0.563 & $(0.574)$ & & & 0.003 & $(0.335)$ \\
\hline $\mathrm{UO}$ - families & & & $0.786^{* *}$ & $(0.334)$ & & & 0.047 & $(0.362)$ & & & 0.187 & $(0.223)$ & & & $0.796^{*}$ & $(0.403)$ & & & 0.115 & $(0.305)$ \\
\hline $\mathrm{UO}$ - foundation & & & $2.587 * * *$ & $(0.675)$ & & & $1.535^{*}$ & $(0.816)$ & & & 0.582 & $(1.058)$ & & & $2.664 * * *$ & $=(0.345)$ & & & $0.578^{* *}$ & $(0.278)$ \\
\hline UO - financial & & & 0.453 & $(0.352)$ & & & -0.282 & $(0.405)$ & & & $0.703^{* *}$ & $(0.322)$ & & & $0.726^{* *}$ & $(0.295)$ & & & $-0.610^{*}$ & $(0.333)$ \\
\hline UO - pension & & & 0.236 & $(0.523)$ & & & $-0.928 * *$ & $(0.363)$ & & & -0.468 & $(0.435)$ & & & -0.217 & $(0.310)$ & & & -0.444 & $(0.318)$ \\
\hline $\mathrm{UO}-\mathrm{VC} / \mathrm{PE}$ & & & $1.553^{*}$ & $(0.896)$ & & & 1.163 & (1.034) & & & -0.332 & $(0.315)$ & & & -0.022 & (1.303) & & & -0.770 & $(0.875)$ \\
\hline UO -- industrial & & & & & & & & & & & & & & & & & & & -0.375 & $(0.291)$ \\
\hline \multicolumn{21}{|l|}{ Controls } \\
\hline ROA & $-0.824 * * *$ & $(0.250)$ & -0.767 & (1.924) & -0.576 & $(0.421)$ & -0.722 & $(2.192)$ & 0.550 & $(0.400)$ & 3.112 & $(1.879)$ & $-2.942 * * *$ & $(0.647)$ & -1.705 & $(3.086)$ & 0.029 & $(0.409)$ & $1.193^{* * *}$ & $=(0.440)$ \\
\hline Interest coverage & 0.000 & $(0.001)$ & 0.004 & $(0.003)$ & 0.001 & $(0.001)$ & 0.004 & $(0.003)$ & -0.001 & $(0.001)$ & 0.002 & $(0.004)$ & 0.002 & $(0.002)$ & -0.003 & $(0.004)$ & -0.001 & $(0.001)$ & $-0.003^{* *}$ & $(0.001)$ \\
\hline Fin. constraints & 0.000 & $(0.004)$ & & & 0.004 & $(0.004)$ & & & 0.004 & $(0.005)$ & & & 0.016 & $(0.010)$ & & & -0.001 & $(0.003)$ & & \\
\hline Financial slack & $-0.040^{* *}$ & $(0.020)$ & & & $-0.035^{*}$ & $(0.021)$ & & & -0.007 & $(0.016)$ & & & -0.040 & $(0.054)$ & & & $-0.061 *$ & $(0.036)$ & & \\
\hline Year FE & Yes & & Yes & & Yes & & Yes & & Yes & & Yes & & Yes & & Yes & & Yes & & Yes & \\
\hline Industry FE & No & & Yes & & No & & Yes & & No & & Yes & & No & & Yes & & No & & Yes & \\
\hline Constant & $-7.824^{*}$ & $(4.420)$ & $-5.945^{* *}$ & $(2.725)$ & $-4.060^{*}$ & $(2.248)$ & -2.032 & $(2.286)$ & -1.299 & $(1.602)$ & 1.095 & $(2.691)$ & $5.384^{* *}$ & $(2.116)$ & 0.157 & (3.123) & 2.121 & $(1.701)$ & 1.372 & $(1.310)$ \\
\hline No. observations & 50783 & & 5342 & & 33295 & & 4090 & & 33431 & & 4084 & & 41889 & & 4740 & & 49891 & & 62557 & \\
\hline$\underline{\text { R-squared adj. }}$ & $5.7 \%$ & & $48.8 \%$ & & $3.6 \%$ & & $45.6 \%$ & & $1.9 \%$ & & $42.4 \%$ & & $3.5 \%$ & & $62.3 \%$ & & $2.8 \%$ & & $24.2 \%$ & \\
\hline
\end{tabular}




\section{Table 6. The Impact of Legal Origins and Political Institutions on Corporate Social Responsibility (Random-Effects Ordered Probit Models).}

The dependent variables are the ordinal (ranging from 0 to 6) EcoValue21 Rating, and Social Rating, respectively. The independent variables are legal origins (omitting the English legal origin as the base case), political institutions (democracy index [the Vanhanen's index], corruption control, and political executive constraints), ownership and governance (ownership dispersion, tier structure or a supervisory board dummy, the ultimate owner [UO] dummies) and control variables (ROA, financial constraints, interest coverage, financial slack). *,**, *** stand for statistical significance at the $10 \%, 5 \%$, and $1 \%$, respectively. Standard errors are reported in parentheses.
(1)
(2)
(3)
(4)
(5)
(6)

\begin{tabular}{|c|c|c|c|c|c|c|}
\hline Dependent Variable & IVA Rating & $\begin{array}{c}\text { Eco value } 21 \\
\text { Rating }\end{array}$ & Social Rating & IVA Rating & $\begin{array}{l}\text { Eco value } \\
21 \text { Rating }\end{array}$ & Social Rating \\
\hline \multicolumn{7}{|l|}{ Law } \\
\hline \multirow[t]{2}{*}{ French origin } & $1.403 * * *$ & $-0.048^{*}$ & $0.181 * * *$ & $0.699 * * *$ & $0.656^{* * *}$ & $0.447 * * *$ \\
\hline & $(0.030)$ & $(0.027)$ & $(0.024)$ & $(0.053)$ & $(0.036)$ & $(0.036)$ \\
\hline \multirow[t]{2}{*}{ German origin } & $2.377 * * *$ & $0.929 * * *$ & 0.040 & $1.758^{* * *}$ & $1.606^{* * *}$ & 0.049 \\
\hline & $(0.033)$ & $(0.027)$ & $(0.026)$ & $(0.041)$ & $(0.030)$ & $(0.033)$ \\
\hline \multirow[t]{2}{*}{ Scandinavian origin } & $2.557 * * *$ & $1.204 * * *$ & $2.128^{* * *}$ & $1.700 * * *$ & $2.067 * * *$ & $1.815^{* * *}$ \\
\hline & $(0.044)$ & $(0.031)$ & $(0.051)$ & $(0.064)$ & $(0.05)$ & $(0.037)$ \\
\hline \multicolumn{7}{|l|}{ Political institutions } \\
\hline \multirow[t]{2}{*}{ Executive constraints } & & & & $-0.054 * *$ & $-0.300 * * *$ & $-0.223^{* * *}$ \\
\hline & & & & $(0.027)$ & $(0.019)$ & $(0.019)$ \\
\hline \multirow[t]{2}{*}{ Corruption control } & & & & $-0.123^{* *}$ & & \\
\hline & & & & $(0.052)$ & & \\
\hline \multicolumn{7}{|l|}{ Economic development } \\
\hline \multirow[t]{2}{*}{ Ln (GDP per capita) } & & & & $0.631 * * *$ & $0.638^{* * *}$ & $0.943^{* * *}$ \\
\hline & & & & $(0.049)$ & $(0.025)$ & $(0.048)$ \\
\hline \multicolumn{7}{|l|}{ Ownership and governance } \\
\hline \multirow[t]{2}{*}{ Ownership dispersion } & & & & 0.001 & $0.025^{* * *}$ & $0.034 * * *$ \\
\hline & & & & $(0.005)$ & $(0.003)$ & $(0.004)$ \\
\hline \multirow[t]{2}{*}{ Board tier structure } & & & & $-0.130 * * *$ & $1.629 * * *$ & $1.399 * * *$ \\
\hline & & & & $(0.027)$ & $(0.033)$ & $(0.038)$ \\
\hline \multicolumn{7}{|l|}{ Controls } \\
\hline \multirow[t]{2}{*}{$\mathrm{ROA}$} & & & & $-1.270^{* * *}$ & $-0.303 * * *$ & $-0.756^{* * *}$ \\
\hline & & & & $(0.179)$ & $(0.105)$ & $(0.203)$ \\
\hline \multirow[t]{2}{*}{ Interest coverage } & & & & -0.0003 & $0.0001^{*}$ & 0.000 \\
\hline & & & & $(0.0004)$ & $(0.0003)$ & $(0.0003)$ \\
\hline \multirow[t]{2}{*}{ Financial constraints } & & & & $0.006^{*}$ & 0.002 & 0.002 \\
\hline & & & & $(0.003)$ & $(0.002)$ & $(0.002)$ \\
\hline \multirow[t]{2}{*}{ Financial slack } & & & & $-0.022 * * *$ & $-0.050 * * *$ & $-0.024 *$ \\
\hline & & & & $(0.008)$ & $(0.007)$ & $(0.010)$ \\
\hline \multirow[t]{2}{*}{ Regulatory quality } & & & & $0.360 * * *$ & $0.318^{* * *}$ & $-0.372 * * *$ \\
\hline & & & & $(0.095)$ & $(0.039)$ & $(0.063)$ \\
\hline No. of observations & 47775 & 90496 & 61119 & 26335 & 51211 & 33596 \\
\hline Log likelihood & -56053.969 & -119273.51 & -80403.812 & -29953.443 & -65409.731 & -42362.352 \\
\hline
\end{tabular}


Table 7. Testing Legal Origins and Political Institutions on Other CSR Data (Random-Effects GLS)

The dependent variables are the different ESG Ratings from MSCI Impact Monitor, Vigeo ESG Ratings, and the Asset4 database, respectively. The independent variables are legal origins (omitting the English legal origin as the base case), political institutions (democracy index, corruption control, and political executive constraints), ownership and governance (ownership dispersion and a supervisory board dummy) and control variables (ROA, interest coverage, and Ln(GDP per capita)). The democracy index used in Column (1), (3)-(7) is from the Vanhanen index. The democracy index used in Column (2), (8)-(9) is from the Polity IV democracy index. *, **, *** stand for statistical significance at the $10 \%, 5 \%$, and $1 \%$, respectively. Standard errors are clustered at the country level and reported in parentheses.

\begin{tabular}{|c|c|c|c|c|c|c|c|c|c|c|c|c|c|c|c|c|c|c|}
\hline & \multicolumn{4}{|c|}{ MSCI Impact Monitor } & \multicolumn{8}{|c|}{ Vigeo ESG } & \multicolumn{6}{|c|}{ Asset 4 ESG } \\
\hline & \multicolumn{2}{|c|}{$\begin{array}{l}\text { Management } \\
\text { Score }\end{array}$} & \multicolumn{2}{|c|}{$\begin{array}{l}\text { Controversy } \\
\text { Score }\end{array}$} & \multicolumn{2}{|c|}{$\begin{array}{c}\text { Corporate } \\
\text { Governance }\end{array}$} & \multicolumn{2}{|c|}{$\begin{array}{c}\text { Human } \\
\text { Resources Rating }\end{array}$} & \multicolumn{2}{|c|}{$\begin{array}{c}\text { Consumer \& } \\
\text { Supplier Rating }\end{array}$} & \multicolumn{2}{|c|}{$\begin{array}{l}\text { Human Rights } \\
\text { Rating }\end{array}$} & \multicolumn{2}{|c|}{$\begin{array}{l}\text { Environmental } \\
\text { Rating }\end{array}$} & \multicolumn{2}{|c|}{ Social Rating } & \multicolumn{2}{|c|}{$\begin{array}{l}\text { Overall CSR } \\
\text { Rating }\end{array}$} \\
\hline & \multicolumn{2}{|c|}{ (1) } & \multicolumn{2}{|c|}{ (2) } & \multicolumn{2}{|c|}{ (3) } & \multicolumn{2}{|c|}{ (4) } & \multicolumn{2}{|c|}{ (5) } & \multicolumn{2}{|c|}{ (6) } & \multicolumn{2}{|c|}{ (7) } & \multicolumn{2}{|c|}{ (8) } & \multicolumn{2}{|c|}{ (9) } \\
\hline \multicolumn{19}{|l|}{ Laws } \\
\hline French origin & $0.723 * *$ & $(0.325)$ & $1.162 *$ & $(0.612)$ & $-18.87 * * *$ & $(2.632)$ & $7.743^{*}$ & $(4.171)$ & 2.088 & $(3.015)$ & $5.766^{* *}$ & $(2.842)$ & $21.411 * *$ & $(9.678)$ & 12.046 & $(9.044)$ & 2.152 & $(8.389)$ \\
\hline German origin & $0.397 * *$ & $(0.185)$ & $1.509 * * *$ & $(0.496)$ & $-22.42 * * *$ & $(2.262)$ & $6.399 * * *$ & $(1.781)$ & -1.624 & $(1.773)$ & -1.253 & $(1.240)$ & $10.729 *$ & $(5.647)$ & -3.437 & $(3.326)$ & $-16.603 *$ & (3.913) \\
\hline Scandinavian origin & $0.772 * *$ & $(0.280)$ & $1.207 * * *$ & $(0.406)$ & $-17.85^{* * *}$ & $(4.638)$ & $7.590 * *$ & $(3.011)$ & $5.070 * * *$ & $(1.893)$ & 3.161 & $(2.959)$ & $22.881 * *$ & $(11.56)$ & $20.925^{* *}$ & $(8.639)$ & $17.273^{* *}$ & $(8.508)$ \\
\hline \multicolumn{19}{|l|}{ Political institutions } \\
\hline Democracy index & -0.007 & $(0.011)$ & -0.046 & $(0.068)$ & 0.100 & $(0.166)$ & -0.000 & $(0.107)$ & $-0.289 * *$ & $(0.115)$ & -0.017 & $(0.119)$ & 0.221 & $(0.722)$ & -1.233 & $(1.536)$ & -1.274 & $(1.613)$ \\
\hline Corruption control & & & 1.052 & $(0.624)$ & & & & & & & & & & & $-16.97 * * *$ & $(2.699)$ & $-18.056^{*}$ & $(2.798)$ \\
\hline Executive constraints & $0.379 * * *$ & $(0.111)$ & & & 1.242 & $(2.162)$ & -1.171 & $(3.763)$ & 2.833 & $(2.349)$ & 0.909 & $(2.179)$ & -2.445 & $(5.311)$ & & & & \\
\hline \multicolumn{19}{|l|}{ Economic development } \\
\hline Ln(GDP per capita) & 0.342 & $(0.529)$ & $-3.168^{* * *}$ & $(0.875)$ & -1.828 & $(4.532)$ & $-15.37 * * *$ & $(3.305)$ & $-10.61 * * *$ & $(2.284)$ & $6.815^{* *}$ & $(3.086)$ & 13.849* & $(7.112)$ & $15.471 * * *$ & $(6.036)$ & $21.329 * *$ & $(5.900)$ \\
\hline Globalization index & $0.045^{* * *}$ & $(0.015)$ & -0.052 & $(0.031)$ & $0.936 * * *$ & $(0.132)$ & $0.637 * * *$ & $(0.132)$ & $0.160^{*}$ & $(0.096)$ & 0.105 & $(0.084)$ & -0.729 & $(0.544)$ & 0.189 & $(0.554)$ & 0.028 & $(0.471)$ \\
\hline \multicolumn{19}{|l|}{ Ownership and governance } \\
\hline Ownership dispersion & 0.040 & $(0.024)$ & $-0.069 *$ & $(0.039)$ & $0.477 * * *$ & $(0.114)$ & 0.119 & $(0.146)$ & 0.055 & $(0.131)$ & $0.251^{* *}$ & $(0.122)$ & 0.238 & $(0.306)$ & 0.252 & $(0.285)$ & $0.737 * * *$ & $(0.270)$ \\
\hline Supervisory board & -0.119 & $(0.244)$ & -0.288 & $(0.824)$ & $4.578^{*}$ & $(2.530)$ & 1.241 & $(2.506)$ & $3.443^{*}$ & $(1.881)$ & 1.662 & $(2.213)$ & 7.575 & $(5.366)$ & $16.893^{* *}$ & $(6.936)$ & $18.097 * *$ & $(6.631)$ \\
\hline \multicolumn{19}{|l|}{ Controls } \\
\hline $\mathrm{ROA}$ & 0.859 & $(1.450)$ & $-3.347^{*}$ & $(1.865)$ & $15.189 * *$ & $(7.706)$ & $-13.91 * *$ & $(6.271)$ & -7.500 & $(5.804)$ & -4.211 & $(4.221)$ & 4.849 & $(4.036)$ & -1.399 & $(7.690)$ & $25.939 * *$ & $(6.324)$ \\
\hline Interest coverage & -0.001 & $(0.003)$ & $0.014 * * *$ & $(0.003)$ & $-0.041 * * *$ & $(0.007)$ & -0.012 & $(0.021)$ & -0.012 & $(0.017)$ & $-0.031 *$ & $(0.017)$ & $-0.037 * * *$ & $(0.009)$ & $-0.000 * * *$ & $(0.000)$ & -0.012 & $(0.013)$ \\
\hline Financial constraints & -0.017 & $(0.012)$ & -0.008 & $(0.020)$ & 0.001 & $(0.003)$ & $-0.013 * * *$ & $(0.001)$ & $-0.011 * * *$ & $(0.001)$ & 0.034 & $(0.160)$ & $-0.004 * * *$ & $(0.001)$ & 0.001 & $(0.001)$ & $-0.006^{* * *}$ & $(0.001)$ \\
\hline Financial slack & 0.165 & $(0.108)$ & -0.114 & $(0.200)$ & 0.777 & $(0.919)$ & $-1.584 * *$ & $(0.610)$ & -0.782 & $(1.001)$ & 0.583 & $(1.168)$ & -0.406 & $(0.709)$ & -0.408 & $(0.715)$ & -1.132 & $(0.711)$ \\
\hline Constant & -5.643 & $(4.674)$ & $42.185^{* * *}$ & $(8.680)$ & -16.365 & $(52.79)$ & $145.87 * *$ & (36.13) & $127.23 * * *$ & $(30.10)$ & $-51.61 *$ & $(31.37)$ & -34.250 & $(49.04)$ & $-92.968 *$ & $(50.82)$ & $-139.42^{*}$ & $(47.15)$ \\
\hline No. of observations & 677 & & 751 & & 4283 & & 4283 & & 4283 & & 3590 & & 13583 & & 13583 & & 13583 & \\
\hline R-square adj. & $8.4 \%$ & & $12.5 \%$ & & $44.2 \%$ & & $28.5 \%$ & & $5.1 \%$ & & $5.3 \%$ & & $6.2 \%$ & & $3.5 \%$ & & $3.6 \%$ & \\
\hline
\end{tabular}




\section{Table 8. Corporate Social Responsibility and Investor Protection Indices (Random-Effects GLS)}

The dependent variables are the ordinal (ranging from 0 to 6) EcoValue21 Rating, and Social Rating, respectively. Only coefficients and robust standard errors for investor protections, legal origins (omitting the English legal origin as the base case), and political institutions (democracy index and political executive constraints) are shown. All regressions control for economic development ( $\operatorname{Ln}($ GDP per capita) and KOF globalization index), ownership and governance (ownership dispersion, tier structure or a supervisory board dummy, firm-level financial variables (ROA, financial constraints, interest coverage, and financial slack), year fixed effects and industry fixed effects. The democracy index used in all columns is from the Vanhanen democracy index, and that used in columns is from the Polity IV democracy index. *,**, *** stand for statistical significance at the $10 \%, 5 \%$, and $1 \%$. Standard errors are clustered at the country level and reported in parentheses.

Dependent Variable is the IVA Rating

\begin{tabular}{|c|c|c|c|c|c|c|}
\hline \multirow{2}{*}{\multicolumn{7}{|c|}{ Investor protection indices }} \\
\hline & & & & & & \\
\hline Adjusted ADRI & $0.393^{* * *}$ & $0.462^{* * *}$ & & & & \\
\hline (highest correlation with LLSV (1998)) & $(0.056)$ & $(0.098)$ & & & & \\
\hline M-R minority rights & & & $\begin{array}{l}0.180^{* * * *} \\
(0.057)\end{array}$ & & & \\
\hline Anti-self-dealing index & & & & $\begin{array}{l}1.842^{* *} \\
(0.910)\end{array}$ & & \\
\hline Public enforcement index & & & & & $\begin{array}{l}0.214 \\
(0.380)\end{array}$ & \\
\hline $\begin{array}{l}\text { Corrected one-share-one-vote } \\
\text { (proportionality of voting and cash flow) }\end{array}$ & & & & & & $\begin{array}{l}0.721 \\
(0.639)\end{array}$ \\
\hline \multicolumn{7}{|l|}{ Law } \\
\hline French origin & & $\begin{array}{l}0.719 * * \\
(0.289)\end{array}$ & $\begin{array}{l}0.704^{* *} \\
(0.382)\end{array}$ & $\begin{array}{l}1.622 * * * \\
(0.459)\end{array}$ & $\begin{array}{l}0.810^{* *} \\
(0.352)\end{array}$ & $\begin{array}{l}0.726^{* *} \\
(0.360)\end{array}$ \\
\hline German origin & & $\begin{array}{l}-0.200 \\
(0.310)\end{array}$ & $\begin{array}{l}0.442^{*} \\
(0.254)\end{array}$ & $\begin{array}{l}1.075^{* * *} \\
(0.361)\end{array}$ & $\begin{array}{l}0.547^{*} \\
(0.330)\end{array}$ & $\begin{array}{l}0.053 \\
(0.525)\end{array}$ \\
\hline Scandinavian origin & & $\begin{array}{l}0.736^{* * *} \\
(0.217)\end{array}$ & $\begin{array}{l}1.664^{* * *} \\
(0.501)\end{array}$ & $\begin{array}{l}1.558^{* * *} \\
(0.409)\end{array}$ & $\begin{array}{l}0.672^{* *} \\
(0.284)\end{array}$ & $\begin{array}{l}0.699 * * \\
(0.305)\end{array}$ \\
\hline \multicolumn{7}{|l|}{ Political institutions } \\
\hline Democracy index & $\begin{array}{l}-0.016 \\
(0.019)\end{array}$ & $\begin{array}{l}-0.041^{* *} \\
(0.05)\end{array}$ & $\begin{array}{l}-0.046^{*} \\
(0.025)\end{array}$ & $\begin{array}{l}-0.021 \\
(0.021)\end{array}$ & $\begin{array}{l}-0.007 \\
(0.027)\end{array}$ & $\begin{array}{l}-0.005 \\
(0.027)\end{array}$ \\
\hline Political executive constraints & $\begin{array}{l}0.063 \\
(0.113)\end{array}$ & $\begin{array}{l}0.167 \\
(0.128)\end{array}$ & $\begin{array}{l}-0.370 \\
(0.303)\end{array}$ & $\begin{array}{l}0.086 \\
(0.111)\end{array}$ & $\begin{array}{l}0.019 \\
(0.104)\end{array}$ & $\begin{array}{l}-0.013 \\
(0.107)\end{array}$ \\
\hline \multicolumn{7}{|l|}{ Economic Development } \\
\hline Ln(GDP per capita) & $\begin{array}{l}0.779 \text { *** } \\
(0.248)\end{array}$ & $\begin{array}{l}0.838^{* * *} \\
(0.247)\end{array}$ & $\begin{array}{l}1.075^{* * *} \\
(0.303)\end{array}$ & $\begin{array}{l}0.761^{* * *} \\
(0.271)\end{array}$ & $\begin{array}{l}0.749 * * * \\
(0.266)\end{array}$ & $\begin{array}{l}0.781 * * * \\
(0.265)\end{array}$ \\
\hline Globalization index & $\begin{array}{l}0.037^{* *} \\
(0.019)\end{array}$ & $\begin{array}{l}0.035^{*} \\
(0.020)\end{array}$ & $\begin{array}{l}0.014 \\
(0.037)\end{array}$ & $\begin{array}{l}0.035^{*} \\
(0.020)\end{array}$ & $\begin{array}{l}0.034 \\
(0.021)\end{array}$ & $\begin{array}{l}0.040^{* *} \\
(0.020)\end{array}$ \\
\hline \multicolumn{7}{|l|}{ Ownership and Governance } \\
\hline Ownership dispersion & $\begin{array}{l}0.026 \\
(0.029)\end{array}$ & $\begin{array}{c}0.043^{*} \\
(0.026)\end{array}$ & $\begin{array}{l}0.096^{* * *} \\
(0.022)\end{array}$ & $\begin{array}{l}0.036 \\
(0.024)\end{array}$ & $\begin{array}{c}0.039 * \\
(0.024)\end{array}$ & $\begin{array}{l}0.034 \\
(0.026)\end{array}$ \\
\hline Supervisory board & $\begin{array}{l}0.464^{* *} \\
(0.214)\end{array}$ & $\begin{array}{l}0.558 \\
(0.402)\end{array}$ & $\begin{array}{l}0.269 \\
(0.193)\end{array}$ & $\begin{array}{l}0.487 \\
(0.322)\end{array}$ & $\begin{array}{l}0.107 \\
(0.251)\end{array}$ & $\begin{array}{l}0.433 \\
(0.428)\end{array}$ \\
\hline \multicolumn{7}{|l|}{ Controls } \\
\hline $\mathrm{ROA}$ & $\begin{array}{l}-0.519 * \\
(0.298)\end{array}$ & $\begin{array}{c}-0.536^{*} \\
(0.302)\end{array}$ & $\begin{array}{l}-0.262 \\
(0.299)\end{array}$ & $\begin{array}{l}-0.558^{*} \\
(0.307)\end{array}$ & $\begin{array}{l}-0.563^{*} \\
(0.307)\end{array}$ & $\begin{array}{c}-0.547 * \\
(0.299)\end{array}$ \\
\hline Interest coverage & $\begin{array}{l}-0.0002 \\
(0.001)\end{array}$ & $\begin{array}{l}-0.0001 \\
(0.001)\end{array}$ & $\begin{array}{l}0.001 \\
(0.001)\end{array}$ & $\begin{array}{l}-0.0001 \\
(0.001)\end{array}$ & $\begin{array}{l}-0.0001 \\
(0.001)\end{array}$ & $\begin{array}{l}-0.0001 \\
(0.001)\end{array}$ \\
\hline No. observations & 33896 & 33896 & 23687 & 33922 & 33922 & 33896 \\
\hline R-squared adj. & $7.9 \%$ & $8.3 \%$ & $12.3 \%$ & $5.9 \%$ & $5.0 \%$ & $4.1 \%$ \\
\hline
\end{tabular}




\section{Table 9. Corporate Social Responsibility and Cultures (Random-Effects GLS)}

The dependent variables are the ordinal (ranging from 0 to 6) IVA Rating, EcoValue21 Rating, and Social Rating, respectively. The independent variables are legal origins (omitting the English legal origin as the base case), political institutions (democracy index, corruption control, and political executive constraints), ownership and governance (ownership dispersion, tier structure or a supervisory board dummy, the ultimate owner [UO] dummies) and control variables (ROA, financial constraints, interest coverage, financial slack, and $\mathrm{Ln}$ (GDP per capita)). The democracy index used in columns (1), (3), and (5) is from Polity IV, and that used in columns (2), (4), and (6) is from the Vanhanen index. The five cultural dimensions are from Hofstede and Hofstede (2005) and measured at the country-level. *, **, *** stand for statistical significance at the $10 \%, 5 \%$, and $1 \%$, respectively. Standard errors are clustered at the firm level for columns (1), (3), and (5), and at the country level for columns (2), (4), and (6), and reported in parentheses.

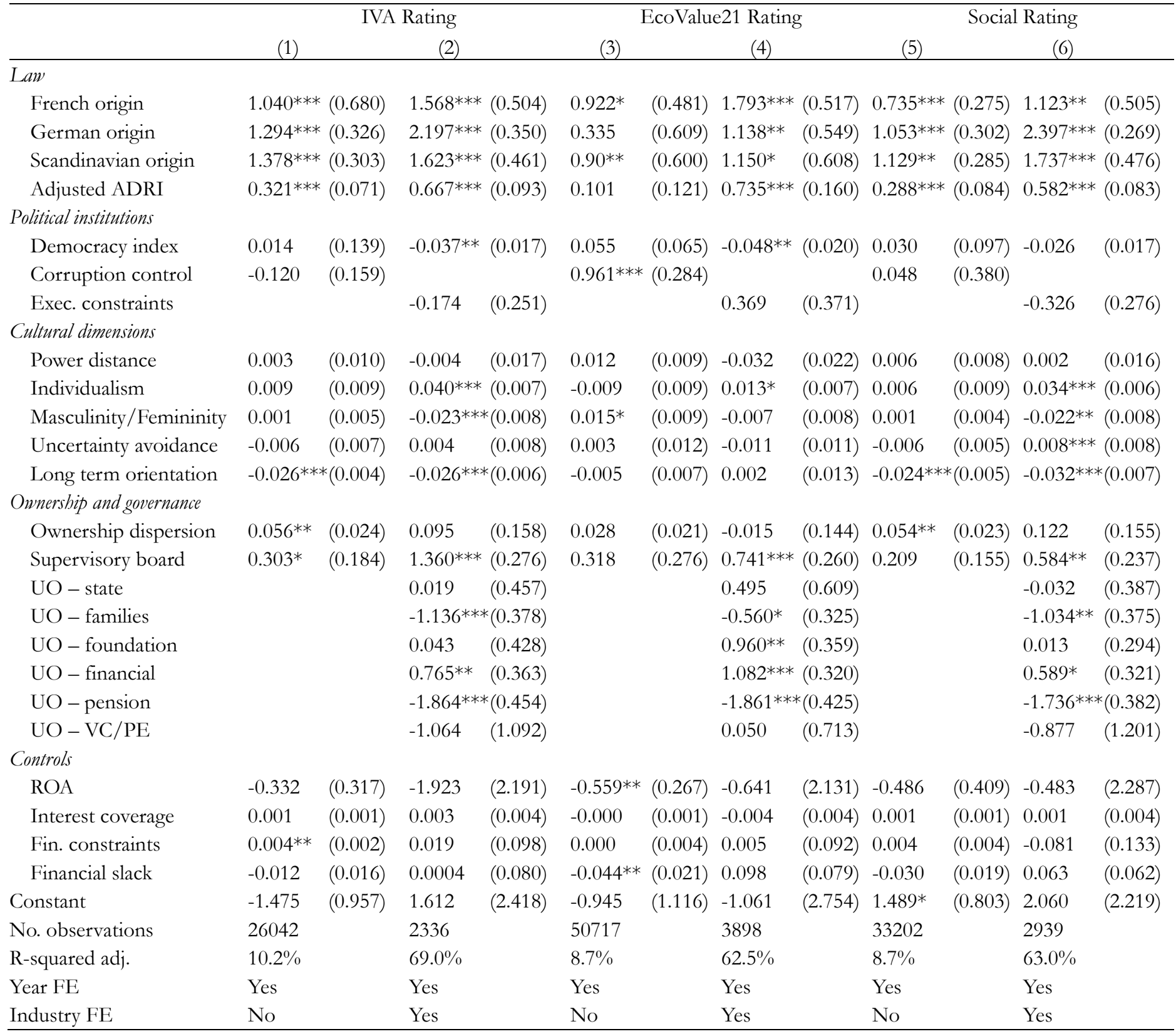




\section{Table 10. The Determinants of Country-Level Sustainability}

The table shows OLS regressions for the cross-section of countries. The dependent variables in Panel A are indicated for each for models (1)-(5). The dependent variable in all specifications of Panels B and $\mathrm{C}$ is the overall sustainable country rating. In Model (1) of Panel A and in Panel C, the Polity IV democracy index is used, and the Vanhanen index is used in models (2)-(5) of Panel A and in Panel B. Each specification includes an unreported constant. Robust standard errors are clustered at the country-level and reported in parentheses. $*, * *, * * *$ stand for statistical significance at the $10 \%, 5 \%$, and $1 \%$, respectively.

\begin{tabular}{|c|c|c|c|c|c|c|c|c|c|c|}
\hline \multicolumn{11}{|c|}{ Panel A. Dependent variable is different country-level sustainability ratings } \\
\hline & \multicolumn{2}{|c|}{$\begin{array}{l}\text { Overall } \\
\text { sustainability rating } \\
\text { (1) }\end{array}$} & \multicolumn{2}{|c|}{$\begin{array}{l}\text { Overall } \\
\text { sustainability rating } \\
\text { (2) }\end{array}$} & \multicolumn{2}{|c|}{$\begin{array}{l}\text { Environmental } \\
\text { sustainability } \\
\text { (3) }\end{array}$} & \multicolumn{2}{|c|}{$\begin{array}{l}\text { Social sustainability } \\
\text { and solidarity } \\
\text { (4) }\end{array}$} & \multicolumn{2}{|c|}{$\begin{array}{l}\text { Institutional } \\
\text { sustainability } \\
\text { (5) }\end{array}$} \\
\hline \multicolumn{11}{|l|}{ Legal origins } \\
\hline French origin & $5.377 * * *$ & $(1.779)$ & $4.936^{* * *}$ & $(1.640)$ & -0.272 & $(0.187)$ & $5.158^{*}$ & $(2.858)$ & $11.40^{* * *}$ & $(2.764)$ \\
\hline German origin & $7.103^{* * *}$ & $(2.123)$ & $7.575^{* * *}$ & $(2.413)$ & $8.028 * * *$ & $(2.456)$ & 4.429 & $(3.570)$ & $9.413^{*}$ & $(4.908)$ \\
\hline Scandinavian origin & $11.691 * * *$ & $(2.283)$ & $11.278^{* * *}$ & $(2.016)$ & $9.305^{* * *}$ & $(3.063)$ & $12.30 * * *$ & $(2.432)$ & $11.08^{* * *}$ & $(2.996)$ \\
\hline Adjusted ADRI & 1.108 & $(0.740)$ & $1.204^{* *}$ & $(0.579)$ & 0.146 & $(0.874)$ & 1.109 & $(1.168)$ & $3.123^{* * *}$ & $(1.108)$ \\
\hline \multicolumn{11}{|l|}{ Political institutions } \\
\hline Democracy index (1960-2000) & 0.344 & $(0.385)$ & 0.088 & $(0.094)$ & -0.136 & $(0.116)$ & 0.227 & $(0.170)$ & 0.248 & $(0.195)$ \\
\hline Corruption control (1996-2008) & 0.372 & $(1.723)$ & & & & & & & & \\
\hline Exec. constraints (1960-2008) & & & 0.229 & $(0.369)$ & 0.579 & $(0.472)$ & -0.039 & $(0.696)$ & 0.187 & $(0.628)$ \\
\hline \multicolumn{11}{|l|}{ Economic development } \\
\hline Ln(GDP per capita) (1960-2011) & 2.325 & $(1.723)$ & 2.573 & $(1.594)$ & -0.008 & $(1.453)$ & $7.097 * * *$ & $(2.093)$ & 2.915 & $(2.896)$ \\
\hline Globalization index (1970-2010) & 0.139 & $(0.111)$ & 0.127 & $(0.114)$ & -0.024 & $(0.114)$ & 0.075 & $(0.158)$ & 0.246 & $(0.244)$ \\
\hline Observations & 41 & & 41 & & 41 & & 41 & & 41 & \\
\hline Adj. R-square & $80.1 \%$ & & $80.2 \%$ & & & & $84.8 \%$ & & $75.1 \%$ & \\
\hline \multicolumn{11}{|c|}{ Panel B. Dependent variable is Overall sustainability country rating } \\
\hline & \multicolumn{2}{|c|}{1970} & \multicolumn{2}{|c|}{1980} & 19 & & \multicolumn{2}{|c|}{2000} & & \\
\hline \multicolumn{11}{|l|}{ Legal origins } \\
\hline French origin & $5.226 * *$ & $(2.107)$ & $4.275^{* *}$ & $(2.074)$ & $4.939 * *$ & $(1.879)$ & $3.306^{*}$ & $(1.873)$ & & \\
\hline German origin & $6.167 * *$ & $(2.806)$ & $6.056^{* *}$ & $(2.603)$ & $7.424 * * *$ & $(2.488)$ & $8.389 * * *$ & $(2.839)$ & & \\
\hline Scandinavian origin & $11.263^{* * *}$ & $(2.655)$ & $10.715^{* * *}$ & $(2.293)$ & $12.30 * * *$ & $(2.605)$ & $10.72^{* * *}$ & $(2.453)$ & & \\
\hline Corrected ADRI & $1.695^{* *}$ & $(0.774)$ & $1.237^{*}$ & $(0.691)$ & 0.769 & $(0.903)$ & 0.932 & $(0.645)$ & & \\
\hline \multicolumn{11}{|l|}{ Political institutions } \\
\hline Democracy index (Vanhanen) & 0.110 & $(0.173)$ & 0.109 & $(0.114)$ & -0.046 & $(0.124)$ & 0.230 & $(0.152)$ & & \\
\hline Executive constraints & 0.150 & $(0.710)$ & -0.213 & $(0.569)$ & 0.664 & $(1.082)$ & -0.036 & $(0.022)$ & & \\
\hline \multicolumn{11}{|l|}{ Economic development } \\
\hline Ln(GDP per capita) & 2.754 & $(2.166)$ & $4.214 * *$ & $(1.710)$ & $2.636^{*}$ & $(1.325)$ & 0.709 & $(1.255)$ & & \\
\hline Globalization index & 0.107 & $(0.178)$ & 0.037 & $(0.137)$ & $0.144^{*}$ & $(0.072)$ & $0.214^{* * *}$ & $(0.072)$ & & \\
\hline Observations & 37 & & 40 & & 41 & & 41 & & & \\
\hline Adj. R-square & $78.9 \%$ & & $80.6 \%$ & & $78.7 \%$ & & $80.3 \%$ & & & \\
\hline \multicolumn{11}{|c|}{ Panel C. Dependent variable is Overall sustainability country rating } \\
\hline & \multicolumn{2}{|c|}{1970} & \multicolumn{2}{|c|}{1980} & \multicolumn{2}{|c|}{1990} & \multicolumn{2}{|c|}{2000} & 20 & \\
\hline Legal origins & & & & & & & & & & \\
\hline French origin & $5.354 * *$ & $(2.085)$ & $4.846^{* *}$ & $(2.123)$ & $5.133^{* *}$ & $(1.975)$ & $5.333 * *$ & $(2.044)$ & $4.020 * *$ & $(1.881)$ \\
\hline German origin & $7.414 * * *$ & $(2.571)$ & $5.813^{* *}$ & $(2.354)$ & $7.436 * * *$ & $(2.418)$ & $8.409 * * *$ & $(2.869)$ & $7.628^{* * *}$ & $(2.203)$ \\
\hline Scandinavian origin & $12.19^{* * *}$ & $(2.989)$ & $11.02 * * *$ & $(2.578)$ & $11.85^{* * *}$ & $(2.843)$ & $12.42 * * *$ & $(3.288)$ & $11.73^{* * *}$ & $(2.408)$ \\
\hline Corrected ADRI & $1.751^{*}$ & $(0.948)$ & $1.324^{*}$ & $(0.764)$ & 0.743 & $(0.794)$ & 0.853 & $(0.777)$ & 0.978 & $(0.841)$ \\
\hline Political institutions & & & & & & & & & & \\
\hline Democracy index (Polity IV) & 0.268 & $(0.315)$ & 0.109 & $(0.314)$ & 0.142 & $(0.676)$ & 0.010 & $(0.029)$ & $1.206^{* *}$ & $(2.408)$ \\
\hline Corruption control (1996-2008) & -0.435 & $(2.568)$ & 0.472 & $(1.691)$ & 1.037 & $(2.044)$ & 1.403 & $(2.148)$ & 0.621 & $(2.044)$ \\
\hline Economic development & & & & & & & & & & \\
\hline Ln(GDP per capita) & 2.807 & $(2.303)$ & $4.242 * *$ & $(1.660)$ & $2.290 * *$ & $(1.061)$ & 1.311 & $(1.103)$ & 0.387 & $(1.664)$ \\
\hline Globalization index & 0.169 & $(0.157)$ & 0.046 & $(0.125)$ & 0.096 & $(0.089)$ & 0.179 & $(0.102)$ & $0.242^{* *}$ & $(0.111)$ \\
\hline Observations & 37 & & 40 & & 41 & & 41 & & 41 & \\
\hline Adj. R-square & $77.9 \%$ & & $80.0 \%$ & & $78.4 \%$ & & $77.4 \%$ & & $84.5 \%$ & \\
\hline
\end{tabular}




\section{Table 11. CSR and Shareholder Value: Two Stage Least Square Regressions}

2SLS regression results for various ESG ratings. In the $1^{\text {st }}$ stage regression (not reported), the dependent variables are various CSR ratings related to labor and social protection, and the independent variables are the country-level employment laws index, collective relations laws index, social security laws index, and civil rights law index developed by Botero et al. (2004). In the second stage, the dependent variable is Tobin's Q measured by the ratio of market capitalization of equity to book value of total assets, and the independent variables are the "predicted" CSR ratings from the $1^{\text {st }}$ stage, together with other control variables. Standard errors are clustered at the firm level for both stages and adjusted by bootstrapping in the $2^{\text {nd }}$ stage. *, **, *** stand for significant at the $10 \%$ level, $5 \%$ level, and $1 \%$ level respectively.

\begin{tabular}{|c|c|c|c|c|c|c|}
\hline \multirow{2}{*}{$\begin{array}{l}\text { Dependent variable is the Tobin's } Q \\
\text { winsorized at } 5 \%\end{array}$} & \multicolumn{4}{|c|}{ MSCI IVA sample } & \multicolumn{2}{|c|}{ Vigeo ESG sample } \\
\hline & Social rating & $\begin{array}{l}\text { Labor } \\
\text { relations }\end{array}$ & $\begin{array}{l}\text { Human } \\
\text { capital }\end{array}$ & $\begin{array}{c}\text { Stakeholder } \\
\text { capital }\end{array}$ & $\begin{array}{l}\text { Human } \\
\text { resources }\end{array}$ & $\begin{array}{l}\text { Human } \\
\text { rights }\end{array}$ \\
\hline CSR (Labor and social protection) & $0.042^{* * *}$ & $0.017 * * *$ & $0.015^{* * *}$ & $0.024 * * *$ & $0.164 *$ & 0.039 \\
\hline (fitted value from the $1^{\text {st }}$ stage) & $(0.003)$ & $(0.004)$ & $(0.003)$ & $(0.004)$ & $(0.090)$ & $(0.111)$ \\
\hline \multirow[t]{2}{*}{ Large shareholders' ownership } & $0.022^{* * *}$ & $0.034 * * *$ & $0.032^{* * *}$ & $0.032 * * *$ & -0.005 & -0.002 \\
\hline & $(0.006)$ & $(0.006)$ & $(0.006)$ & $(0.005)$ & $(0.011)$ & $(0.010)$ \\
\hline \multirow[t]{2}{*}{ Capital Expenditure (scaled) } & $-0.407 * * *$ & $-0.407 * * *$ & $-0.408^{* * *}$ & $-0.415^{* *}$ & -0.183 & -0.173 \\
\hline & $(0.142)$ & $(0.156)$ & $(0.133)$ & $(0.162)$ & $(0.134)$ & $(0.110)$ \\
\hline \multirow[t]{2}{*}{ Dividends payout } & $0.019 * * *$ & $0.019^{* * *}$ & $0.019 * * *$ & $0.019 * * *$ & 0.0002 & 0.0002 \\
\hline & $(0.004)$ & $(0.005)$ & $(0.005)$ & $(0.004)$ & $(0.001)$ & $(0.001)$ \\
\hline \multirow[t]{2}{*}{ Leverage } & $-0.038^{* * *}$ & $-0.038^{* * *}$ & $-0.038^{* * *}$ & $-0.038 * * *$ & $-0.385^{* * *}$ & $-0.381 * * *$ \\
\hline & $(0.001)$ & $(0.001)$ & $(0.001)$ & $(0.001)$ & $(0.064)$ & $(0.068)$ \\
\hline \multirow[t]{2}{*}{$\mathrm{ROA}$} & $-0.244 * * *$ & $-0.202^{* * *}$ & $-0.215^{* * *}$ & $-0.205^{* * *}$ & $-0.395^{* * *}$ & $-0.402 * * *$ \\
\hline & $(0.028)$ & $(0.028)$ & $(0.033)$ & $(0.032)$ & $(0.089)$ & $(0.099)$ \\
\hline \multirow[t]{2}{*}{ Financial constraints } & $0.155^{* * *}$ & $0.133^{* * *}$ & $0.135^{* * *}$ & $0.150 * * *$ & 0.343 & 0.343 \\
\hline & $(0.026)$ & $(0.023)$ & $(0.024)$ & $(0.029)$ & $(0.577)$ & $(0.527)$ \\
\hline \multirow[t]{2}{*}{ Interest coverage } & $0.177 * * *$ & $0.160^{* * *}$ & $0.164 * * *$ & $0.167 * * *$ & $0.275^{* * *}$ & $0.276^{* * *}$ \\
\hline & $(0.007)$ & $(0.007)$ & $(0.007)$ & $(0.008)$ & $(0.019)$ & $(0.023)$ \\
\hline \multirow[t]{2}{*}{ Financial slacks } & $0.053^{* * *}$ & $0.054^{* * *}$ & $0.054^{* * *}$ & $0.054^{* * *}$ & $-0.080^{* * *}$ & $-0.081 * * *$ \\
\hline & $(0.002)$ & $(0.002)$ & $(0.002)$ & $(0.002)$ & $(0.016)$ & $(0.015)$ \\
\hline \multirow[t]{2}{*}{ Investment opportunities } & $0.330^{* * *}$ & $0.330^{* * *}$ & $0.330^{* * *}$ & $0.335^{* * *}$ & $0.098 * * *$ & $0.097 * * *$ \\
\hline & $(0.102)$ & $(0.112)$ & $(0.095)$ & $(0.126)$ & $(0.036)$ & $(0.035)$ \\
\hline \multirow[t]{2}{*}{ Constant } & $0.236 * * *$ & $0.265^{* * *}$ & $0.271 * * *$ & $0.220 * * *$ & $42.859 * * *$ & $45.882^{* * *}$ \\
\hline & $(0.011)$ & $(0.023)$ & $(0.015)$ & $(0.023)$ & $(2.992)$ & $(4.774)$ \\
\hline Year FE & Yes & Yes & Yes & Yes & Yes & Yes \\
\hline Industry FE & Yes & Yes & Yes & Yes & Yes & Yes \\
\hline No. observations & 27430 & 27430 & 27430 & 27430 & 2126 & 2126 \\
\hline Adj. R-square & $43.9 \%$ & $43.5 \%$ & $43.6 \%$ & $43.7 \%$ & $50.9 \%$ & $50.8 \%$ \\
\hline
\end{tabular}




\title{
Appendix. Definitions of Independent Variables
}

Variable

\author{
Definition
}

I. Law

Legal origins

ode of each

Anti-director
rights index

(ADRI) distinguish five major legal origins: English common law, French commercial code (civil law), German commercial code (civil law), Scandinavian civil law, and Socialist law. Source: LLSV (1998).

The anti-director rights index (ADRI) was first developed in LLSV (1998) as a measure of investor protection against corporate management, and later on revised in La Porta et al. (2008) and Spamann (2010). All the three ADRIs consist of the same six key components: (1) proxy by mail allowed; (2) shares not blocked before shareholder meeting; (3) cumulative voting/ proportional representation; (4) oppressed minority protection; (5) preemptive rights to new share issues; (6) percentage of share capital to call an extraordinary shareholder meeting. Each component is a dummy variable and the ADRI is formed by aggregating the value of all six components. The index ranges from 0 to 6 , whereby a higher value of the index indicates stronger shareholder protection. Source: LLSV (1998); La Porta et al. (2008); Spamann (2010).

Martynova-

Renneboog (M-R) The M-R index compromises three subindices on corporate governance regulations since 1990 in 30 European countries corporate governance index and the US. The three subindices covering 50 dimensions correspond to three types of agency conflicts: (1) between shareholder and manager, (2) between majority and minority shareholders, and (3) between shareholders and creditors. The index includes the following regulatory standards: (1) shareholder and creditor protection regulation, (2) accounting standards, (3) disclosure rules, (4) takeover regulation (mandatory bid, squeeze-out rules, takeover defense measures, etc.), (5) insider trading regulation, (6) regulation regarding the structure of the board of directors and voting power distribution, and (7) adoption of codes of good practice. Source: Martynova and Renneboog (2011).

\section{Political Institutions}

Vanhanen's index Tutu Vanhanen's index of democracy is computed by multiplying the political competition and political participation variables (also defined and calculated by WDR2011) and by dividing the outcome by 100 . Higher value of the index implies higher level of democracy. The Vanhanen's measure on political competition is used to denote the electoral success of the smaller parties (i.e., the proportion of the votes won by those parties in parliamentary and/or presidential elections) to indicate the degree of competition in a political system. This index is calculated by subtracting the percentage of the votes won by the largest party from 100 percent. The Vanhanen's measure on political participation is the percentage of the population that actually voted in these elections (electoral participation). The total population is used as denominator and not the adult or enfranchised population). A combination of the two variables is expected to yield a more realistic indicator of democratization than either as a stand-alone measure. Source: PRIO/CSCW - World Bank.

Polity IV Institutionalized Democracy: Democracy is conceived as three essential, interdependent elements: (i) the presence of democracy index institutions and procedures through which citizens can express effective preferences about alternative policies and leaders; (ii) the existence of institutionalized constraints on the exercise of power by the executive; (iii) the guarantee of civil liberties to all citizens in their daily lives and in acts of political participation. Other aspects of plural democracy, such as the rule of law, systems of checks and balances, freedom of the press, and so on are means to, or specific manifestations of, these general principles. The Democracy indicator is an additive eleven-point scale (0-10). Higher value of the index implies higher level of democracy. Source: Polity IV.

Democracy ranking index

The Democracy ranking is the index that measures the quality of democracy based on political (among others, Freedom House, CPI, etc.) and socioeconomic factors and is available for 100 countries from 2001. It is carried by the Democracy Ranking Association ("Democracy Ranking Association - Förderung von Demokratiequalität") in Vienna, Austria. http://www.democracyranking.org. Higher value of the index implies higher level of democracy.

Freedom house political rights index

Unified

democracy score The Freedom house political rights Index is offered by World Bank's World Development Report, and is measured by the extent political rights in a country as calculated by Freedom House. Coded from 1-7 (7 being the worst). The order of rating is then reversed in our paper. Therefore, higher value of the index signifies higher level of democracy. The Unified democracy scores (UDS) combines measures from 12 existent democracy measures (among others, Freedom House, Polity, Polyarchy, Vanhanen) and is available for all the countries worldwide between 1946 and 2008. The index goes from -2.5 to 3.5 whereby a higher score signifies higher level of democracy.

Economist intelligence unit democracy index The Economist Intelligence Unit's democracy index is based on 60 indicators grouped in five different categories: electoral process and pluralism, civil liberties, functioning of government, political participation, and political culture. In addition to a numeric score and a ranking, the index categorizes countries as one of four regime types full democracies, flawed democracies, bybrid regimes, and authoritarian regimes. The index was first produced for 2006, with updates for 2008, 2010, 2011 , and 2012. Higher value of the index implies a higher level of democracy.

Polyarchy

democracy index

Political executive constraints

The Polyarchy Democracy index is based on Robert Dahl's (1971) concept of polyarchy. These are Guttman scales, and their component variables, measuring levels of the contestation dimension of polyarchy in every independent state in the world as of mid-2000. Higher value of the index implies a higher level of democracy. Source: Brinks and Coppedge (2006). Political Executive Constraints (Decision Rules): (1) Unlimited Authority: There are no regular limitations on the political executive's actions (as distinct from irregular limitations such as the threat or actuality of coups and assassinations); (2) Intermediate Category; (3) Slight to Moderate Limitation on Political Executive Authority: There are some real but limited restraints on the executive; (4) Intermediate Category; (5) Substantial Limitations on Political Executive Authority: The executive has more effective authority than any group to which is it is accountable but the executive is subject to substantial constraints that group imposes in it; (6) Intermediate Category; (7) Executive Parity or Subordination: Accountability groups have effective authority equal to or greater than the executive in most areas of activity. Source: Polity IV.

Corruption

control The extent to which public power is exercised for private gain, including petty and grand forms of corruption, as well as the "capture" of the state by elites and private interests. Coded from -2.5 to 2.5 with higher values corresponding with better governance outcomes. Source: World Governance Indicator - World Bank.

Regulatory quality The ability of the government to formulate and implement sound policies and regulations that permit and promote private sector development. Coded from -2.5 to 2.5 with higher values corresponding with better governance outcomes. Higher value of the index implies a higher level of regulatory quality. Source: World Governance Indicator - World Bank. 


\section{Economic Development}

GDP per capita GDP per capita is gross domestic product divided by midyear population. GDP is the sum of gross value added by all resident producers in the economy plus any product taxes and minus any subsidies not included in the value of the products. It is calculated without making deductions for depreciation of fabricated assets or for depletion and degradation of natural resources. Data are in current U.S. dollars. Source: World Bank.

Globalization The KOF Index of Globalization measures the three main dimensions of globalization: (1) economic, (2) social, and (3) index political. In addition to three indices measuring these dimensions, an overall index of globalization and sub-indices are also calculated referring to (1) actual economic flows, (2) economic restrictions, (3) data on information flows, (4) data on personal contact, and (5) data on cultural proximity. Data are available on a yearly basis over the period 1970-2010. A higher score indicates higher degree of globalization. Source: Swiss Federal Institute of Technology Zurich (ETH).

\section{Cultures}

Power distance "Power distance" deals with the fact that all individuals are not equal and is defined as the extent to which the less powerful members of institutions and organizations within a country expect and accept that power is distributed unequally. The concept captures whether or not a society's inequality is endorsed by the followers as much as by the leaders. A higher score signifies a large power distance between individuals. Source: Hofstede and Hofstede (2005).

Individualism Individualism is the degree of interdependence a society maintains among its members and defines people's self-image in terms of "I" or "We". In individualist societies, people are supposed to look only after themselves and their direct family whereas in collectivist societies people belong to 'in groups' that take care of them in exchange for loyalty. A higher score indicates more individualism in society. Source: Hofstede and Hofstede (2005).

Masculinity/ Femininity

A high score on the Masculinity/Femininity dimension indicates that a masculine society is driven by competition, achievement and success, with success being defined by the "winner" or "best-in-the-field." This value system starts in school and continues throughout one's life - both in work and leisure pursuits. A low score means that the dominant values in the feminine society consist of caring for others and quality of life. A feminine society is one where quality of life is the sign of success and standing out from the crowd is not admirable. The fundamental issue here is what motivates people, wanting to be the best (masculine) or liking what you do (feminine). Source: Hofstede and Hofstede (2005).

Uncertainty avoidance Uncertainty avoidance represents how a society deals with the fact that the future is uncertain: should one try to control the future or just let it happen? This ambiguity brings with it anxiety and different cultures have learnt to deal with this anxiety in different ways. The extent to which the members of a culture feel threatened by ambiguous or unknown situations and have created beliefs and institutions that try to avoid these is reflected in the UAI score. A higher score implies a higher level of uncertainty avoidance. Source: Hofstede and Hofstede (2005).

Long term orientation Long term orientation is closely related to the teachings of Confucius and can be interpreted as dealing with society's search for virtue, the extent to which a society shows a pragmatic future-oriented perspective rather than a conventional historical short-term point of view. Source: Hofstede and Hofstede (2005).

\section{Ownership and Governance}

Ownership dispersion

Bureau van Dijk's Independence indicator shows different categories ranging from A to D. Category A (divided into A+, A, and A-) represents the group of "independent companies" and consists of companies without any shareholders holding more than $25 \%$ of the direct or total ownership. Category B (divided into B+, B, and B-) consists of companies without shareholders holding more than $50 \%$ of direct, indirect or total ownership, but with one or more shareholders holding more than $25 \%$ of direct or total ownership. Category C (divided into C+ and C) represents the group of "indirectly majority owned companies" and consists of companies without shareholder holding more than $50 \%$ of direct ownership, but with one shareholder holding more than $50 \%$ of total ownership. Category D represents the group of "directly majority owned companies" and consists of companies with one shareholder holding more than $50 \%$ of direct ownership. The ratings translated into these numbers: $\mathrm{A}+=9, \mathrm{~A}=8, \mathrm{~A}=7, \mathrm{~B}+=6, \mathrm{~B}=5, \mathrm{~B}=4, \mathrm{C}+=3, \mathrm{C}=2, \mathrm{D}=1$. Source: Orbis.

$\mathrm{UO}$ - state The ultimate owner (UO) is the state, the government or a public authority. UO stands for the percentage of direct voting rights owned by this shareholder who is identified by following the path of uninterrupted control rights (at 50\%) throughout the ownership pyramid. Source: Orbis.

UO - families The ultimate owner (UO) of the subject company is one or more named individuals or families. For the definition of UO: see (Ultimate owner - state). Source: Orbis.

$\mathrm{UO}$ - foundation The ultimate owner (UO) of the subject company is a foundation or research institute. For the definition of UO: see (Ultimate owner - state). Source: Orbis.

$\mathrm{UO}$ - financial The ultimate owner (UO) of the subject company is a bank or financial company, or an insurance company. For the definition of UO: see (Ultimate owner - state). Source: Orbis.

$\mathrm{UO}$ - pension

$\mathrm{UO}-\mathrm{VC} / \mathrm{PE}$

$\mathrm{UO}$ - industrial The ultimate owner (UO) of the subject company is a mutual fund or pension fund, or a nominee/trust/trustee from the pension fund. For the definition of UO: see (Ultimate owner - state). Source: Orbis.

The ultimate owner (UO) is a venture capital or private equity firm. For the definition of UO: see (Ultimate owner - state). Source: Orbis.

The ultimate owner (UO) of the subject company is an industrial conglomerate. For the definition of UO: see (Ultimate owner - state). Source: Orbis.

Supervisory board Dummy variable which equals one if the subject company has a supervisory board, and zero otherwise. Source: Orbis.

\section{Financial Performance and Constraints}

ROA Return on assets: net income divided by total assets. Source: Compustat.

Fin. constraints Measured by the ratio of the change in short-term investment to the change in operational cash flow. Source: Compustat.

Interest coverage Earnings before interests and taxes (EBIT) divided by interest expenses. Source: Compustat.

Financial slack Current ratio, calculated as the current debts divided by current assets. Source: Compustat. 